\title{
Evolution of Bundelkhand Craton
}

\author{
${ }^{1}$ Department of Earth and Planetary Sciences, Nehru Science Centre, University of Allahabad, Allahabad-211002, Uttar Pradesh, India; \\ E-mail : jkpati@gmail.com \\ ${ }^{2}$ National Centre of Experimental Mineralogy and Petrology, 14, Chatham Lines, University of Allahabad, Allahabad-211002, Uttar Pradesh, \\ India
}

(Received : 16/01/2019; Revised accepted : 23/07/2019)

https://doi.org/10.18814/epiiugs/2020/020004

The Indian subcontinent is a repository of Archean cratonic nuclei with plethora of geoscientific data to better understand the early Earth evolution and the operating processes. The Bundelkhand Craton $(\mathrm{BuC})$ in the north-central India is one of the five Archean cratons which preserves signatures of Paleoarchean magmatism, Archean subduction, Neoarchean metamorphism, spectacular craton-scale landforms as a testimony of Paleoproterozoic episodic silico-thermal fluid activity and plume-generated mafic magmatism, and a Paleoproterozoic meteoritic impact event, currently the seventh oldest in the world. Based on available geological and geophysical data, the BuC has been divided into north $\mathrm{BuC}(\mathrm{NBuC})$ and south $\mathrm{BuC}(\mathrm{SBuC})$ across the Bundelkhand Tectonic Zone (BTZ). The evolution of BuC has many similarities with other Indian cratons and the available geochronological data suggest that it forms a part of the Ur Supercontinent.

\section{Introduction}

The formation, geodynamic evolution, physics and chemistry of the interiors of the terrestrial planets are best studied in the thin veneer of the planetary crust. The evidences of Hadean events, giant meteoritic impacts, mantle mineralogy and mass extinctions lie frozen as time capsules in crustal rocks. However, the vestiges of sensustricto Hadean to Archean crusts are rarely observed in pristine state. The cratons, shields and associated greenstone belts conspicuously preserve the signatures of the juvenile Earth. In India, there are five cratons of Archean age (Aravalli, Bastar, Bundelkhand, Dharwar (Eastern and Western) and Singhbhum; Fig. 1a) in the large expanse of peninsular shield occupying nearly 7,50,000 sq $\mathrm{km}$ area and displaying comparable lithological, deformational, metamorphic, chronological and evolutionary history (Table1). Unlike other Indian cratons, about two decades ago, very little was known from the Bundelkhand Craton (Basu, 1986) and till 2010, it was considered to be "relatively less studied” (Meert et al., 2010). The reported paucity of geochronological data, lack of mineralization, so-called undeformed monotonous nature of granitic rocks and metamorphism up to upper amphibolite facies did not attract desired attention even though the Bundelkhand Craton (BuC) exposures occupied nearly 29,000 sq km area in parts of north central India (Fig. 1b). It is bounded by the Proterozoic Vindhyan Basin on all sides excluding the northern part where the cratonic appendage is concealed below the Indo-Gangetic Alluvium (Basu, 1986; Naqvi and Rogers, 1987; Goodwin, 1991; Meert et al., 2010; Ray et al., 2015; Manglik et al., 2015; Meert and Pandit, 2015). Patches of basaltic outcrops (Deccan Traps) are observed to the SSW and SW marginal portions. The Great Boundary Fault (GBF), the Central Indian Tectonic Zone (CITZ) and the Himalayan Frontal Thrust (HFT) are the three major tectonic elements which constrain the surface disposition of the BuC to its western, southern and northern boundaries, respectively (Naqvi and Rogers, 1987; Goodwin, 1991; Malviya et al., 2006; Pati et al., 2008a, 2008b; Meert et al., 2010; Bhattacharya and Singh, 2013; Ray et al., 2015; Meert and Pandit, 2015).

In recent years, meaningful data from the $\mathrm{BuC}$ on granitoid geochemistry (Hussain et al., 2004, Ram Mohan et al., 2012; Kaur et al., 2016, Ramiz and Mondal, 2017; Joshi et al., 2017, Chauhan et al., 2018; Singh et al., 2019), quartz reefs (Pati et al., 2007; Raut et al., 2017), mafic magmatism (Rao et al., 2005, Mondal and Ahmad, 2001, Pati et al., 2008b, Pradhan et al., 2010, Singh et al., 2018), metamorphic imprints (Prasad et al., 1999, Pati, 1999, Singh et al., 2007; Singh and Dwivedi, 2009, 2015; Saha et al., 2011; Pati and Saha, 2011; Kaur et al., 2016) and geochronology (Sarkar et al., 1996, Mondal et al., 2002; Malviya et al., 2006, Pati et al., 2011, Kaur et al., 2016, Verma et al., 2016, Saha et al., 2016) have been generated. The largest impact structure of SE Asia with an estimated diameter of $11 \mathrm{~km}$, the Dhala structure also occurs in the NW fringe of BuC (Pati, 2005 and Pati et al., 2008a). Here, an attempt has been made to synthesize and evaluate the available geological data pertaining to the evolution of $\mathrm{BuC}$ and discuss new findings unique to this craton.

\section{Rock types of the Bundelkhand Craton}

Petrological studies comprising various rock types are mainly collected from parts of Kabrai-Mahoba-Babina-Talbehat-BansiLalitpur-Madaura areas which are exposed along the National (NH26) and State Highways. The rocks are described mainly using geochemical (major and trace element) data. Mineral analysis and isotopic data were largely absent except in some recent studies in 


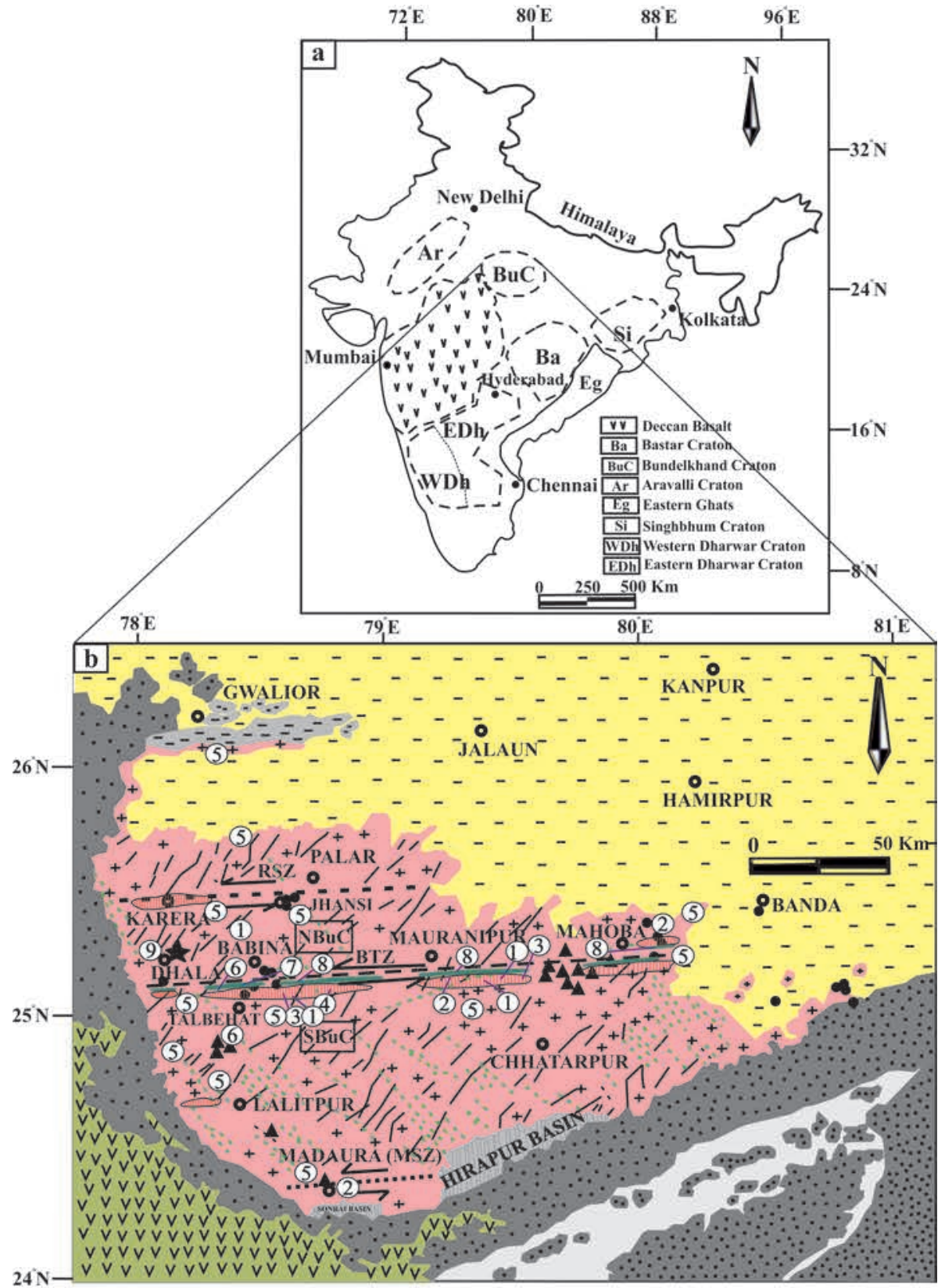

\section{LEGEND}

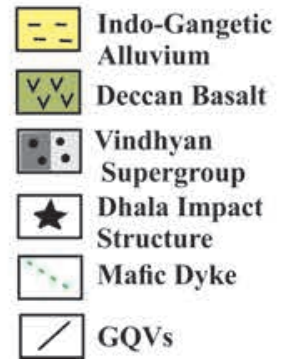

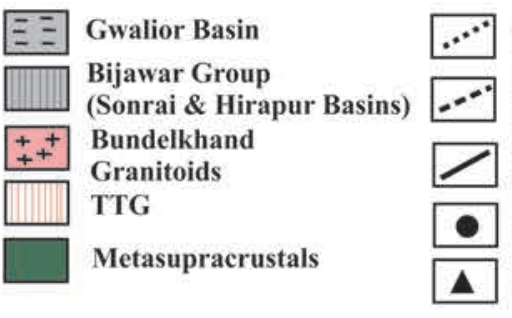

Madaura Shear Zone (MSZ)

Raksa Shear Zone (RSZ)

Bundelkhand Tectonic Zone (BTZ)

Molybdenite Incidences

Gold Incidences

Figure 1. a) Archean cratonic nuclei of the peninsular Indian shield occupy nealy 7,50,000 sq km area. b) Enlarged geological map of Bundelkhand Craton (BuC). Bundelkhand Tectonic Zone (BTZ) divides the BuC into two parts: NBuC and SBuC based on geological and geophysical data.

BuC (Pati et al., 2010; Pati et al; 2015; Kaur et al., 2016; Saha et al., 2016; Joshi et al., 2017; Pati et al., 2017; Singh et al., 2019; Singh et al., 2019; Nasipuri et al., 2019; Alfimova et al., 2019). The lithology mainly comprises tonalite-trondhjemitegranodioritic (TTG) gneisses, metasupracrustals (amphibolites, banded iron formation, komatiitic basalts ( $\sim$ modern boninite), metaperidotite, calc-silicate rocks, corundum-bearing phengite schist, quartzsericite schists, fuchsite quartzite and quartzite), granitic rocks (plutonic, hypabyssal and volcanic variants), giant quartz veins, mafic dykes and some noritic intrusions in the western part of BuC (Basu, 1986; Sarkar et al., 1996; Sharma and Rahman, 2000; Mondal et al., 2002; Malviya et al., 2006; Pati et al., 2007; Saha et al., 2011, 2016; Kaur et al., 2016; Verma et al., 2016; Joshi et al., 2017; Singh et al., 2018; Roy et al., 2018; Nasipuri et al., 2019; Singh et al., 2019; Alfimova et al., 2019).

\section{Tonalite-Trondhjemite- Granodiorite Gneisses (TTGs)}

The TTGs of varying ages ( 3.6-2.7 Ga) occur as kilometer-size enclaves within alkali granitoid gneisses of Archean age in the vicinity of BTZ mainly (Mondal et al., 2002; Kaur et al., 2014, 2016; Saha et al., 2016; Joshi et al., 2017; Nasipuri et al., 2019). The outcrops are best exposed between WSW of Dhala and S of Babina to Paswara-Kabrai (Fig. 4d). Mineralogically, TTGs are mainly composed of plagioclase feldspar, quartz, biotite, calcic-amphibole and K-feldspar having epidote, zircon, monazite, apatite and titanite as accessory phases (Ray et al., 2015; Chauhan et al., 2018). The ubiquitous association of the metasupracrustals with the greenstones component, especially amphibolites, is similar to their world-wide occurrences. The TTGs of the BuC are evolved between diorite and granite, dominantly sodic to marginally potassic in composition and show medium- to low-heavy rare earth element (low-HREE) character with low Eu subgroups (Ram Mohan et al., 2012; Joshi et al., 2017). Based on geochemical data, Ram Mohan et al. (2012) classified TTGs of BuC into two distinct categories: Sodic/True TTG and Potassic/Transitional TTG which were derived from two different sources. But Joshi et al. (2017) preferred to characterize them as Low-HREE TTG and Enriched TTG based on their distinctive rare earth element (REE) patterns. The sodic group shows relatively more fractionated REE pattern as compared to the potassic group of TTGs (Ram Mohan et al., 2012). They have high $\mathrm{SiO}_{2}$ (64.1774.52 wt. \%) and $\mathrm{Na}_{2} \mathrm{O}$ (3.11-5.90 wt. \%), moderate to high (La/ $\mathrm{Yb})_{\mathrm{CN}}$ and $\mathrm{Sr} / \mathrm{Y}$ values (14.7-33.50 and 4.85-98.7, respectively) with 
Table 1. Stratigraphy with order of emplacement of different intrusives in Bundelkhand Granitoid Complex. Abbreviations (Act: Actinolite, Aln: Allanite, Amp: Amphibole, Ap: Apatite, Bt: Biotite, Cal: Calcite, Chl: Chlorite, Cln: Clinochlore, Cpx: Clinopyroxene, Crn: Corundum, Ep: Epidote, Hbl: Hornblende, Ilm: Ilmenite, Grt: Garnet, Mag: Magnetite, Mnz: Monazite, Opq: Opaque, Opx: Orthopyroxene, Phl: Phlogopite, Plag: Plagioclase, Px: Pyroxene, Qtz: Quartz, Sr: Sericite, Sp: Sphene, Wo: Wollastonite, Zr:Zircon)

\begin{tabular}{|c|c|c|c|c|}
\hline Lithological Units & Field Characters & $\begin{array}{l}\text { Mineralogical } \\
\text { Assemblages }\end{array}$ & Age $(M a / G a)$ & References \\
\hline Vindhyan Supergroup & $\begin{array}{l}\text { Sedimentary rocks (sandstone, } \\
\text { limestone etc.) }\end{array}$ & $\begin{array}{c}\mathrm{Qtz}+\mathrm{Or} \pm \mathrm{Plag} \pm \mathrm{Bt} \pm \\
\mathrm{Hbl}\end{array}$ & $\sim 1.6 \mathrm{Ga}$ & Sarangi et al., 2004 \\
\hline Mafic dykes & $\begin{array}{l}\text { Moderate relief and highly } \\
\text { jointed. dark greenish grey in } \\
\text { colour, fine to medium grained } \\
\text { with ophitic to sub-ophitic } \\
\text { texture. }\end{array}$ & $\begin{array}{c}\text { Plag } \pm \mathrm{Cpx} \pm \mathrm{Ol} \pm \mathrm{Qtz} \\
\pm \mathrm{Ilm} \pm \mathrm{Mag}\end{array}$ & $1.1-1.97 \mathrm{Ga}$ & $\begin{array}{l}\text { Sarkar et al., 1997; Sharma and } \\
\text { Rahman, 2000; Rao et al., } \\
\text { 2005; Pati et al., 2008b; } \\
\text { Pradhan et al., 2012; } \\
\text { Radhakrishna et al., } 2013\end{array}$ \\
\hline $\begin{array}{l}\text { Giant quartz veins } \\
\text { (GQVs) }\end{array}$ & $\begin{array}{l}\text { Trend: NNE-SSW to N-S. Fault } \\
\text { breccias and subhorizontal } \\
\text { stretching } \\
\text { preserved. }\end{array}$ & $\begin{array}{c}\mathrm{Qtz} \pm \mathrm{Sr} \pm \mathrm{Ep} \pm \mathrm{Opq} \\
\pm \mathrm{Cal}\end{array}$ & $1.9-2.2 \mathrm{Ga}$ & $\begin{array}{l}\text { Sarkar et al., 1984; Rao et al., } \\
\text { 2005; Pati et al., } 2007\end{array}$ \\
\hline $\begin{array}{l}\text { Rhyolite/ Granophyre/ } \\
\text { Granite Porphyry }\end{array}$ & $\begin{array}{l}\text { Pinkish brown in colour, } \\
\text { massive in nature and } \\
\text { extensively fractured. Euhedral } \\
\text { feldspar grains and blue quartz } \\
\text { present. }\end{array}$ & $\begin{array}{l}\mathrm{Qtz}+\mathrm{Or} \pm \mathrm{Plag} \pm \mathrm{Bt} \\
\pm \mathrm{Hbl} \pm \mathrm{Ep} \pm \mathrm{Chl}\end{array}$ & $2.5 \pm 7 \mathrm{Ga}$ & Mondal et al., 2002 \\
\hline Karera Gneiss & $\begin{array}{l}\text { Enclaves within alkali granitoid } \\
\text { gneisses. }\end{array}$ & $\begin{array}{c}\mathrm{Qtz}+\mathrm{Plag} \pm \mathrm{Bt} \pm \mathrm{Hbl} \pm \\
\mathrm{Ep}\end{array}$ & $\sim 2.56 \pm 6 \mathrm{Ga}$ & $\begin{array}{l}\text { Mondal et al., 2002; Saha et al., } \\
2010\end{array}$ \\
\hline Intrusive Granitoids & $\begin{array}{l}\text { Variations in colour, texture and } \\
\text { mineralogy. Syenites are rare. } \\
\text { Pegmatites are mostly } \\
\text { anhydrous in nature. }\end{array}$ & $\begin{array}{c}\text { Qtz }+ \text { Or } \pm \text { Plag } \pm \text { Bt } \pm \\
\text { Hbl } \pm \text { Ep }\end{array}$ & $1.9-2.59 \mathrm{Ga}$ & $\begin{array}{l}\text { Mondal et al., 2002; Pati et al., } \\
\text { 2010; Saha et al., 2011; Kumar } \\
\text { et al., 2013; Singh and } \\
\text { Slabunov, 2013, 2015; Kaur et } \\
\text { al., 2016; Verma et al., 2016; } \\
\text { Joshi et al., 2017; Singh et al., } \\
2019\end{array}$ \\
\hline $\begin{array}{l}\text { Sanukitoids and anatectic } \\
\text { granites }\end{array}$ & $\begin{array}{l}\text { Outcrops are mostly } \\
\text { undeformed, multiphase } \\
\text { emplacement in all older units }\end{array}$ & $\begin{array}{c}\mathrm{Plag}+\mathrm{Hbl} \pm \mathrm{Qtz} \pm \text { Or } \pm \\
\mathrm{Bt} \pm \mathrm{Zr} \pm \mathrm{Ap} \pm \mathrm{Aln} \pm \\
\mathrm{Mnz} \pm \mathrm{Ttn} \text { and Qtz }+ \\
\mathrm{Or}+\mathrm{Plag} \pm \mathrm{Bt} \pm \mathrm{Hbl} \pm \\
\mathrm{Zr} \pm \mathrm{Ap} \pm \mathrm{Mnz} \pm \mathrm{Ttn} \pm \\
\mathrm{Aln}\end{array}$ & $2.59-2.46 \mathrm{Ga}$ & $\begin{array}{l}\text { Mondal et al., 2002; Pandey et } \\
\text { al., 2011; Saha et al., 2011; } \\
\text { Kumar et al., 2013; Kaur et al., } \\
\text { 2016; Verma et al., 2016; Joshi } \\
\text { et al., 2017; Singh et al., } \\
2019\end{array}$ \\
\hline $\begin{array}{l}\text { Tonalite-Trondhjemite- } \\
\text { Granodiorite Gneisses } \\
\text { (TTGs) }\end{array}$ & $\begin{array}{l}\text { Basement unit, Enclaves within } \\
\text { alkali granitoid gneisses. } \\
\text { Associated with greenstone } \\
\text { component. }\end{array}$ & $\begin{array}{c}\mathrm{Qtz}+\mathrm{Plag} \pm \mathrm{Bt} \pm \mathrm{Hbl} \pm \\
\mathrm{Ep}\end{array}$ & $\sim 3.6-2.7 \mathrm{Ga}$ & $\begin{array}{l}\text { Sarkar et al., 1995; Mondal et } \\
\text { al., 2002; Singh and Slabunov, } \\
\text { 2013; Singh and Slabunov, } \\
\text { 2014, 2015; Kaur et al., 2014, } \\
\text { 2016; Saha et al., 2011, 2016; } \\
\text { Verma et al., 2016; Joshi } \\
\text { et al., 2017; Singh et al., } \\
\text { 2019; Nasipuri et al., } \\
2019\end{array}$ \\
\hline Calc-silicates & $\begin{array}{l}\text { Associated with amphibolites, } \\
\text { quartzites and BIFs. At few } \\
\text { places with karst-like } \\
\text { topography. }\end{array}$ & $\begin{array}{c}\text { Amp }+\mathrm{Di}+\mathrm{Qtz}+\mathrm{K}- \\
\mathrm{Na} \text { feldspar }+\mathrm{Ap} \pm \mathrm{Cal} \\
\pm \mathrm{Wo}\end{array}$ & $\longrightarrow$ & - \\
\hline $\begin{array}{l}\text { Corundum-Phlogopite- } \\
\text { Phengite Schists }\end{array}$ & Occurring within TTGs & $\mathrm{Crn}+\mathrm{Phl}+\mathrm{Chl}+\mathrm{Cln}$ & $\begin{array}{l}\sim 2.78 \mathrm{Ga}(\sim \text { age of } \\
\text { metamorphism) } \sim 2.47 \mathrm{Ga} \\
(\sim \text { exhumation age })\end{array}$ & Saha et al., 2011 \\
\hline Felsic volcanics & $\begin{array}{l}\text { Less deformed unit, usually } \\
\text { occur at base of BIFs and and } \\
\text { at some paces, in the form of } \\
\text { dykes }\end{array}$ & $\mathrm{Qtz}+\mathrm{Plag}+\mathrm{Bt}+\mathrm{Hbl}$ & $2.81-2.54 \mathrm{Ga}$ & $\begin{array}{l}\text { Slabunov et al., 2013; Singh } \\
\text { and Slabunov, 2014, 2015; } \\
\text { Joshi et al., 2017; Slabunov and } \\
\text { Singh, } 2018\end{array}$ \\
\hline $\begin{array}{l}\text { Banded Iron Formations } \\
\text { (BIFs) }\end{array}$ & $\begin{array}{l}\text { Associated } \\
\text { metasupracustals, quartzites, } \\
\text { granitoid gneisses etc. } \\
\text { Composed of alternating } \\
\text { layers of iron-rich and } \\
\text { amorphous silica-rich } \\
\text { materials. Show multiple } \\
\text { phases of folding. }\end{array}$ & $\begin{array}{c}\text { Mag }+ \text { Qtz } \pm \text { Opx } \pm \\
\mathrm{Cpx} \pm \text { Grt } \pm \text { Hbl } \pm \text { Act } \\
\pm \mathrm{Bt} \pm \text { Chl } \pm \text { Ap } \pm \text { Aln }\end{array}$ & $2.82-2.81 \mathrm{Ga}$ & $\begin{array}{l}\text { Slabunov et al., 2013; Singh } \\
\text { and Slabunov, 2013, } 2015\end{array}$ \\
\hline Amphibolites & $\begin{array}{l}\text { Mostly associated with } \\
\text { greenstone components. At } \\
\text { some places, observed as } \\
\text { enclaves within granitoids and } \\
\text { gneisses. }\end{array}$ & $\begin{array}{c}\mathrm{Hbl}+\mathrm{Plag} \pm \mathrm{Grt} \pm \mathrm{Bt} \pm \\
\mathrm{Chl} \pm \mathrm{Qtz} \pm \mathrm{Mag} \pm \mathrm{Sp} \pm \\
\mathrm{Ap} \pm \mathrm{Zr} \pm \mathrm{Mnz}\end{array}$ & $\begin{array}{l}\text { 4.9-4.2 Ga (possibly } \\
\text { protolith age) } 3.4-3.3 \mathrm{Ga} \\
\text { ( age of metamorphism) }\end{array}$ & $\begin{array}{l}\text { Malviya et al., 2005; Singh et } \\
\text { al., } 2019\end{array}$ \\
\hline
\end{tabular}


Table 2. Correlation of Paleo- Mesoarchaean crustal components of Bundelkhand Craton with that recorded from other Archean cratons of Peninsular India (modified after Saha et al., 2016)

\begin{tabular}{|c|c|c|c|c|c|c|}
\hline Age & $\begin{array}{l}\text { Bundelkhand } \\
\text { Craton }\end{array}$ & Aravalli Craton & Singhbhum Craton & Bastar Craton & $\begin{array}{c}\text { Western Dharwar } \\
\text { Craton }\end{array}$ & $\begin{array}{c}\text { Eastern Dharwar } \\
\text { Craton }\end{array}$ \\
\hline 2.8-2.5 Ga & $\begin{array}{l}\text { High-pressure } \\
\text { metamorphism, } \\
\text { felsic magmatism } \\
\text { (Saha et al., 2011; } \\
\text { Mondal et al., 2002; } \\
\text { Singh and Slabunov, } \\
\text { 2014, 2015; } \\
\text { Slabunov and Singh, } \\
\text { 2018; Joshi et al., } \\
\text { 2017; Singh et al., } \\
\text { 2019) }\end{array}$ & $\begin{array}{l}\text { Crystallisation ages } \\
\text { of Banded Gneissic } \\
\text { Complex, Berach } \\
\text { Granite (Roy et al., } \\
\text { 2012) }\end{array}$ & $\begin{array}{l}\text { Crystallization ages of } \\
\text { MayurBhanj Granite, } \\
\text { eastern and western } \\
\text { margins of Singhbhum } \\
\text { Craton (Saha et al., 1977; } \\
\text { Mishra et al.,1999; } \\
\text { Bandyopadhyay et al., } \\
\text { 2001) }\end{array}$ & Not recorded & $\begin{array}{l}\text { Supracrustal sequence } \\
\text { and potassic granite } \\
\text { (Meen et al., 1992; } \\
\text { Nutman et al., 1992, } \\
\text { 1996; Peucat et al., } \\
\text { 1993; 1995; } \\
\text { Ramakrishnan et al., } \\
\text { 1994) }\end{array}$ & $\begin{array}{l}\text { TTG magmatism } \\
\text { and intrusion of } \\
\text { potassic granite } \\
\text { (Jayananda et al., } \\
\text { 2000) }\end{array}$ \\
\hline 3.2-3.0 Ga & $\begin{array}{l}\text { U-Pb zircon ages } \\
\text { recorded from the } \\
\text { TTG gneiss in the } \\
\text { Sukwa-Dukwa dam } \\
\text { area and near } \\
\text { Panchwara (Mondal } \\
\text { et al., 2002; Saha et } \\
\text { al., 2011; Kaur et al., } \\
\text { 2016) }\end{array}$ & $\begin{array}{l}\text { U-Pb zircon ages } \\
\text { from the Alwar } \\
\text { quartzite of Aravalli } \\
\text { Supergroup (Kaur et } \\
\text { al., 2011) }\end{array}$ & $\begin{array}{l}\text { U-Pb zircon overgrowth in } \\
\text { the magmatic zircons from } \\
\text { Older Metamorphic } \\
\text { Tonalitic Gneiss and } \\
\text { detrital zircons from Older } \\
\text { Metamorphic Group } \\
\text { (Mishra et al., 1999) }\end{array}$ & Not recorded & $\begin{array}{l}\text { Pb-Pb zircon ages } \\
\text { obtained from the TTG } \\
\text { gneisses of Nuggihalli } \\
\text { schist belt and } \\
\text { orthogneiss clast in } \\
\text { Kaladurga conglomerate } \\
\text { (Maibam et al., 2011) }\end{array}$ & $\begin{array}{l}\text { Pb-Pb zircon age } \\
\text { from the } \\
\text { Sakarsanhalli TTG } \\
\text { gneiss (Maibam et } \\
\text { al., 2011) }\end{array}$ \\
\hline $3.3 \mathrm{Ga}$ & $\begin{array}{l}\mathrm{Pb}-\mathrm{Pb} \text { zircon ages } \\
\text { from Kuraicha and } \\
\text { Mahoba gneisses; } \\
\text { Pb-Pb zircon age } \\
\text { from the metabasic } \\
\text { enclave in Mahoba } \\
\text { Gneiss (Mondal et } \\
\text { al., 2002) }\end{array}$ & $\begin{array}{l}\text { Whole rock Sm-Nd } \\
\text { and Pb-Pb zircon } \\
\text { ages from Mewar } \\
\text { Gneiss (Gopalan et } \\
\text { al., 1990; } \\
\text { Wiedenbeck \& } \\
\text { Goswami, 1994); U- } \\
\text { Pb detrital zircon } \\
\text { ages from the Alwar } \\
\text { quartzite of Aravalli } \\
\text { Supergroup (Kaur et } \\
\text { al., 2011) }\end{array}$ & $\begin{array}{l}\text { Pb-Pb zircon ages from } \\
\text { Singhbum Granite-II } \\
\text { (Mishra et al., 1999) }\end{array}$ & Not recorded & $\begin{array}{l}\text { U-Pb zircon ages from } \\
\text { Gorur gneiss } \\
\text { (Beckinsale et al., } \\
\text { 1980; Peucat et al., } \\
\text { 1993); U-Pb zircon ages } \\
\text { from the meta rhyolite } \\
\text { of Holenarsipur } \\
\text { supracrustal units } \\
\text { (Peucat et al., 1995); } \\
\text { whole rock Sm-Nd } \\
\text { isochron age from } \\
\text { Komatiite of Sargur } \\
\text { supracrustal unit } \\
\text { (Jayananda et al., 2008) }\end{array}$ & $\begin{array}{l}\text { Pb-Pb zircon age } \\
\text { from Hulimavu } \\
\text { orthogneiss } \\
\text { (Maibam et al., } \\
\text { 2011) }\end{array}$ \\
\hline $3.4 \mathrm{Ga}$ & $\begin{array}{l}\text { U-Pb zircon age } \\
\text { from Babina TTG } \\
\text { gneiss (Mondal et } \\
\text { al., 2002; Singh and } \\
\text { Slabunov, 2013; } \\
\text { Kaur et al., 2014, } \\
\text { Saha et al., 2016; } \\
\text { Joshi et al., 2017; } \\
\text { Singh et al., 2019; } \\
\text { Nasipuri et al., 2019) }\end{array}$ & Not recorded & $\begin{array}{l}\text { Pb-Pb zircon ages from } \\
\text { Older Metamorphic } \\
\text { Tonalite Gneiss and } \\
\text { Singhbhum granite Phase- } \\
\text { I (Mishra et al., 1999; } \\
\text { Acharyaa et al., 2010) }\end{array}$ & Not recorded & $\begin{array}{l}\text { Pb-Pb detrital zircon } \\
\text { ages from the Sargur } \\
\text { supracrustal units } \\
\text { (Maibam et al., 2011) }\end{array}$ & Not recorded \\
\hline 3.6-2.7 Ga & $\begin{array}{l}\text { U-Pb zircon, Pb-Pb } \\
\text { zircon and whole } \\
\text { rock Rb-Sr age from } \\
\text { TTGs (Sarkar et al., } \\
\text { 1995; Mondal et al., } \\
\text { 2002; Singh and } \\
\text { Slabunov, 2013; } \\
\text { Kaur et al., 2014, } \\
\text { 2016; Singh and } \\
\text { Slabunov, 2014, } \\
\text { 2015; Saha et al., } \\
\text { 2011, 2016; Verma } \\
\text { et al., 2016; Joshi et } \\
\text { al., 2017; Singh et } \\
\text { al., 2019; Nasipuri } \\
\text { et al., 2019) }\end{array}$ & Not recorded & $\begin{array}{l}\text { U-Pb zircon ages from the } \\
\text { felsic volcanics of Iron } \\
\text { Ore Group } \\
\text { (Mukhopadhyay et al., } \\
\text { 2008); Pb-Pb detrital } \\
\text { zircon ages from the Older } \\
\text { Metamorphic Group } \\
\text { (Goswami et al., 1995; } \\
\text { Mishra at al., 1999). }\end{array}$ & $\begin{array}{l}\text { U-Pb zircon } \\
\text { ages from TTG } \\
\text { gneiss and } \\
\text { granite (Ghosh, } \\
\text { 2004; Rajesh et } \\
\text { al., 2009) }\end{array}$ & $\begin{array}{l}\text { U-Pb detrital zircon ages } \\
\text { from the Sargur } \\
\text { supracrustal units } \\
\text { (Nutman et al., 1992) }\end{array}$ & Not recorded \\
\hline 4.03-4.24Ga & Not recorded & Not recorded & $\begin{array}{l}\text { U-Pb zircon ages from } \\
\text { Paleoarchean ( 3.4 Ga) } \\
\text { Older Metamorphic } \\
\text { Gneiss (OMTG), } \\
\text { Champua area (Chaudhuri } \\
\text { et al., 2018) }\end{array}$ & Not recorded & Not recorded & Not recorded \\
\hline $\begin{array}{l}4.9-4.2 \mathrm{Ga} \\
\text { and } 3.4-3.3 \\
\text { Ga }\end{array}$ & $\begin{array}{l}\text { Based on Nd } \\
\text { isotopic values, the } \\
\text { possible protolith } \\
\text { and metamorphic } \\
\text { ages of amphibolites } \\
\text { (Malviya et al., } \\
\text { 2005) }\end{array}$ & Not recorded & Not recorded & Not recorded & Not recorded & Not recorded \\
\hline
\end{tabular}


low Mg\# (30-47) and HREE contents which indicate their genesis by partial melting of the sub-arc hydrous basaltic crust under a specific pressure-temperature condition (Ram Mohan et al., 2012; Chauhan et al., 2018). The outcrop-scale features, whole rock geochemistry of TTGs and Hf isotopic data from zircon suggest reworking of both felsic and mafic components between 3.55 and 3.20 Ga followed by the emplacement of granitoids at around 2.5 Ga (Kaur et al., 2016; Saha et al., 2016; Nasipuri et al., 2019). It demonstrates a multifaceted process of crustal formation and stabilization during that time and indicates an Archean metamorphic overprint at ca. 3.20 Ga just after the last phase of TTGs magmatism in the BuC (Kaur et al., 2016). These geochemical data also suggest that both mafic magmatic enclaves and host granitoids are formed by the injection of hot mafic magma into a relatively cooler granitic magma chamber in a subduction setting (Ramiz and Mondal, 2017).

\section{Metasupracrustals associated with greenstone belts}

Babina-Paswara (Bundelkhand Greenstone Belt; Pati, 1999; Malviya et al., 2006; Saha et al., 2011) and Rungaon-Girar greenstone belts are well exposed in BuC (Singh and Slabunov, 2015; Saha et al., 2016; Slabunov and Singh, 2018). The lithology of these belts is mainly composed of amphibolites, banded iron formation, pillow basalts, komatiitic basalts, calc-silicate rocks, white schists, quartzites, metavolcanics, metapelites, mafic-ultramafics (Basu, 1986; Mondal et al., 2002; Malviya et al., 2006; Pati et al., 2007; Ram Mohan et al., 2012; Kaur et al., 2014; Singh and Slabunov, 2015; Kaur et al., 2016; Saha et al., 2016; Verma et al., 2016; Joshi et al., 2017; Slabunov et al., 2017; Singh et al., 2018, 2019; Nasipuri et al., 2019). Some lithounits of these belts are also intruded by K-rich pink granites at many places (Singh et al., 2007; 2018). A NE-SW-trending quartz reef shows sinistral displacement of the supracrustals near Mankua village (Basu, 1986; Pati et al., 2007; Saha et al., 2011; Singh et al., 2018). Based on geochemical and geochronological studies, several workers have suggested a subduction-related tectonic setting for the volcano-sedimentary rocks of Babina-Paswara greenstone belt (Malviya et al., 2006; Saha et al., 2010; Singh and Slabunov, 2015, Saha et al., 2016; Kaur et al., 2016; Singh et al., 2018).

Recently, Singh et al. (2019) reported geochemical and Sm-Nd isotopic data from mafic and ultramafic rocks of the Babina and Mauranipur greenstone belts. It revealed that they evolved through fractional crystallization associated with crustal assimilation and have metamorphosed up to greenschist to amphibolites facies (Singh et al., 2010; Singh et al., 2019). These geochemical analyses of mafic, ultramafic and felsic volcanic rocks endorse the Neoarchean plumearc accretion setting in the Bundelkhand greenstone belts. The age of pink granite and granodiorite which intrude the greenstone sequence has been suggested as ca. 2500 Ma (Mondal et al., 2002; Kumar et al., 2010; Kaur et al., 2016; Joshi et al., 2017) while the Mesoarchean Bundelkhand gneiss associated with Archean greenstone belt is dated between 3551 and 3270 Ma (Sarkar et al., 1996; Mondal et al., 2002; Kaur et al., 2014; Saha et al., 2016; Nasipuri et al., 2019).

\section{Amphibolites}

Amphibolites are mainly exposed along the $\sim$ E-W-trending Bundelkhand Tectonic Zone (BTZ; Pati 1999) associated with greenstone components (BIF, calc-silicate rocks, white schists, quartzites and metapelites). They are also observed as enclaves within granitoids and gneisses (Fig. 2a). Mineralogically amphibolites contain hornblende + plagioclase \pm garnet \pm biotite \pm chlorite \pm quartz \pm magnetite \pm sphene \pm apatite \pm zircon \pm monazite etc. (Pati and Saha, 2011). Using hornblende-plagioclase thermo-barometry, the amphibolites show a polybaric (1.7-5.92 kb) and near isothermal (599$641^{\circ} \mathrm{C}$ ) P-T conditions of their equilibration. Their major element chemistry shows a dominantly calc-alkaline affinity and limited tholeiitic character. They are large-ion lithophile elements (LILE; Ba, Sr) enriched and high field strength elements (HFSE; Nb, Zr, Hf, Ta and Ti; Malviya et al., 2005) depleted. The REE pattern shows unfractionated to fractioned characteristics. The marked $\mathrm{Nb}$ and $\mathrm{Ta}$ depletions observed in MORB-normalized data suggest that these amphibolites are meta-basalts that are comparable to the modern-day basaltic magma observed in convergent plate settings (Malviya et al., 2005). The Nd isotopic values of amphibolites along the BTZ are highly variable $\left({ }^{143} \mathrm{Nd} /{ }^{144} \mathrm{Nd}\right.$ : $\left.0.511509-0.512626\right)$ and yield two model age clusters around 4.9-4.2 Ga (possibly protolith age) and 3.4-3.3 Ga ( age of metamorphism). The Nd isotopic measurements suggest that the amphibolites were formed in a subduction-related tectonic setting from a depleted mantle during the Archean time.

\section{Pillow basalts}

The pillowed metabasalt (Fig. 2b) exposures are restricted to Pal Basti, Bargaon area of Mauranipur, Uttar Pradesh (Malviya et al., 2006). They show very high aspect ratio suggesting their flattening in a compressive stress domain. Mineralogically, they comprise hornblende, plagioclase, magnetite, epidote, chlorite and quartz. Chemically, they are depleted in HFSEs with Nb- and Ta-troughs characteristics of volcanic arc magma and they are similar to low-K arc tholeiite observed in modern plate convergent boundaries.

\section{Banded iron formations (BIFs)}

Banded iron formations (BIFs) in BuC are disposed as alternating iron-rich and silica-rich layers (Fig. 2c) similar to other Indian cratons and different parts of the world. The BIFs occur in association with quartzite \pm amphibolites (Fig. 2d) \pm metamorphosed pillow basalts \pm metamorphosed ultramafic rocks \pm volcaniclastic metasediments \pm calc-silicate rocks \pm granitoid gneisses as dismembered lenses mainly confined to the BTZ in areas like Babina, Prithvipura (Jhansi), Sukwan-Dukwan (Jhansi), Papaoni, Gora, Balyara, Kuraicha (Jhansi), Mauranipur (Jhansi), Santhar (Mahoba) and Bijainagar-ThanasagarPaswara (Mahoba). The BIFs occur as largely E-W-trending bands of varying width (up to tens of $m$ ) with bedding||foliation ( \pm shear) dipping steeply towards north. The BIFs show three phases of folding and are sinistrally displaced along NE-SW to NNE-SSW direction up to a km (Mankua, near Babina, Jhansi; Basu, 1986). They are metamorphosed between greenschist to upper amphibolite/granulite facies (Pati, 1999). The mineralogy includes: magnetite (Mag), \pm quartz (Qtz), \pm orthopyroxene (Opx), \pm clinopyroxene (Cpx), \pm garnet ( $\mathrm{Grt}_{\mathrm{ss}}$ ), \pm hornblende (Hbl), \pm actinolite (Act), \pm biotite (Bt), \pm chlorite (Chl), apatite (Ap) and \pm allanite (Aln). The BIF has three distinct mineral assemblages (1. Mag + Amp + Chl + Ap + Qtz; 2. Mag + $\mathrm{Grt}_{\mathrm{ss}}+\mathrm{Opx}+\mathrm{Cpx}+\mathrm{Ap}+\mathrm{Qtz}$; and 3. Mag + Amp + Chl + $\mathrm{Grt}_{\mathrm{ss}}+\mathrm{Ap}$ + Qtz; Fig. 3). The geochemical analysis shows 43.14 to 52.71 wt. \% of $\mathrm{Fe}_{2} \mathrm{O}_{3}$ within BIFs of Babina area while in Girar, it varies between 31.57 and 40.03 wt. \% (Singh and Slabunov, 2015, 2016). However, 

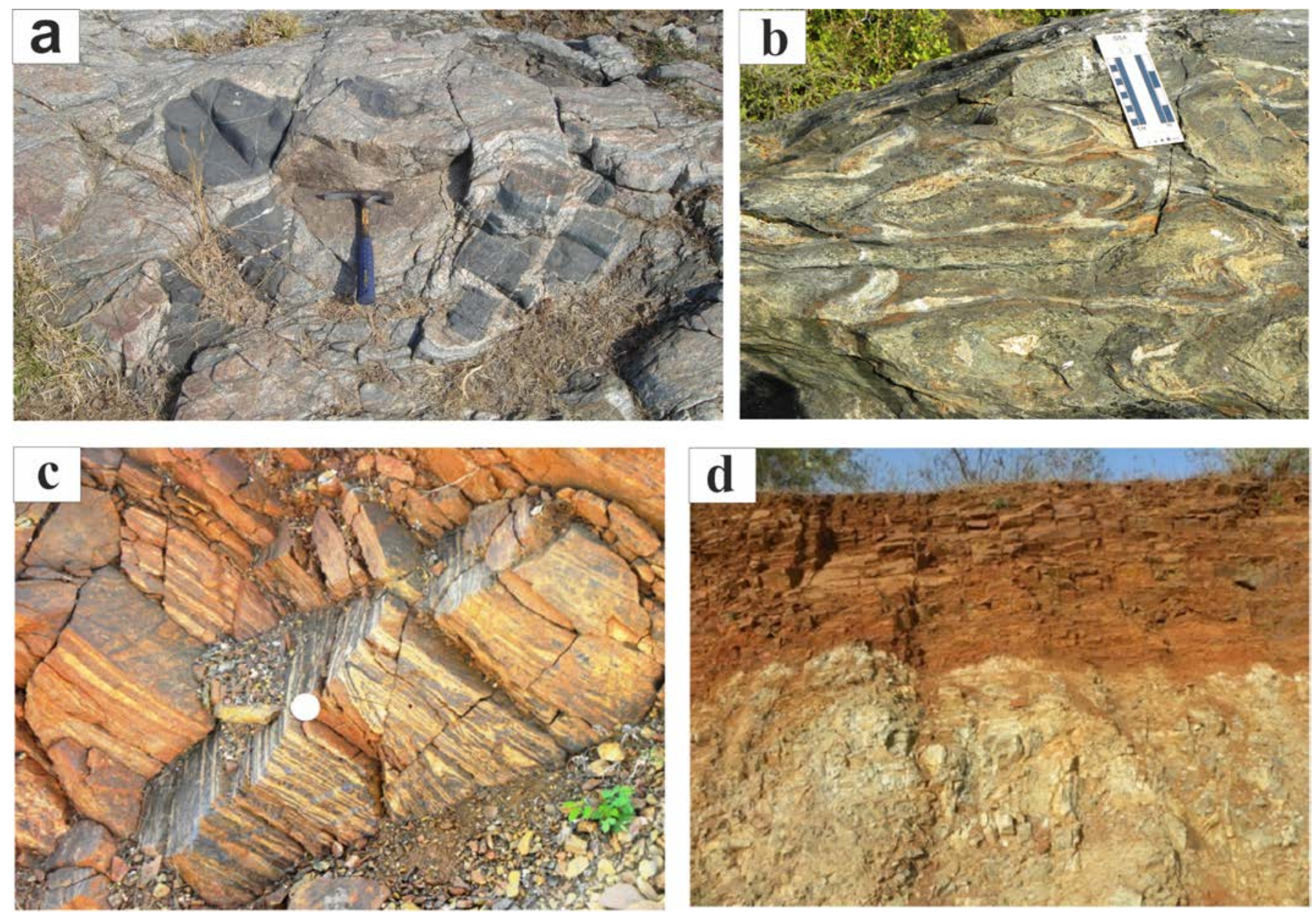

Figure 2. Field photographs. a) Amphibolites occurring as enclaves within TTG gneiss. b) Flattened pillow basalt (with very high aspect ratio) exposed in Pal Basti, Bargaon area of Mauranipur. c) Profile section of folds in Banded Iron Formation (BIF). These alternate bands are mainly composed of magnetite (dark brown) and silica (pale yellow). d) Irregular and diffused contact between amphibolite (pale green) and BIF (reddish brown) in a vertical section.

the FeO content in the BIFs of Mauranipur (19.97-23.13 wt. \%) is higher as compared to the BIFs of Babina and Girar areas (Singh et al., 2018). Major element compositions of the BIFs show wide variations in iron and manganese contents although $\mathrm{SiO}_{2}, \mathrm{Al}_{2} \mathrm{O}_{3}$ and $\mathrm{TiO}_{2}$ remain similar from west to east along the $\mathrm{BTZ}$. The MnO content in Babina area is minimum (0.01 to 0.14 wt. \%) compared to Mauranipur (1.72-4.08 wt. \%) and Mahoba (2.05-3.73 wt. \%) suggesting a possible shallowing of the proto-basin to the east (Malviya et al., 2013). The REE data of Mauranipur BIFs suggest a volcanogenic-hydrothermal source for the derivation of chemogenic sediments whereas the Mahoba BIFs provide evidence for a continental source (Malviya et al., 2013). In general, BIFs are more enriched in $\mathrm{Cr}$ and $\mathrm{Ni}$ as compared to $\mathrm{Zr}, \mathrm{Hf}, \mathrm{Ba}$, Th, Sr, $\mathrm{Yb}$ and $\mathrm{Lu}$ with a positive Eu-anomaly (Singh and Slabunov, 2016). In Babina area, they have lower concentration of $\mathrm{Nb}$, $\mathrm{Ti}$ and $\mathrm{Zr}$ which indicate their association with island-arc volcanism (Singh and Slabunov, 2015). Although in Girar, the higher concentration of $\mathrm{Cr}$ and $\mathrm{Ni}$ in BIFs indicate their occurrence with mafic-ultramafic magmatism (Singh and Slabunov, 2016). The formation of BIFs took place under varied physico-chemical conditions during the Archean time in multiple basins in the central part of BuC with each basin having its separate sediment source (Malviya et al., 2013). In Mauranipur, the

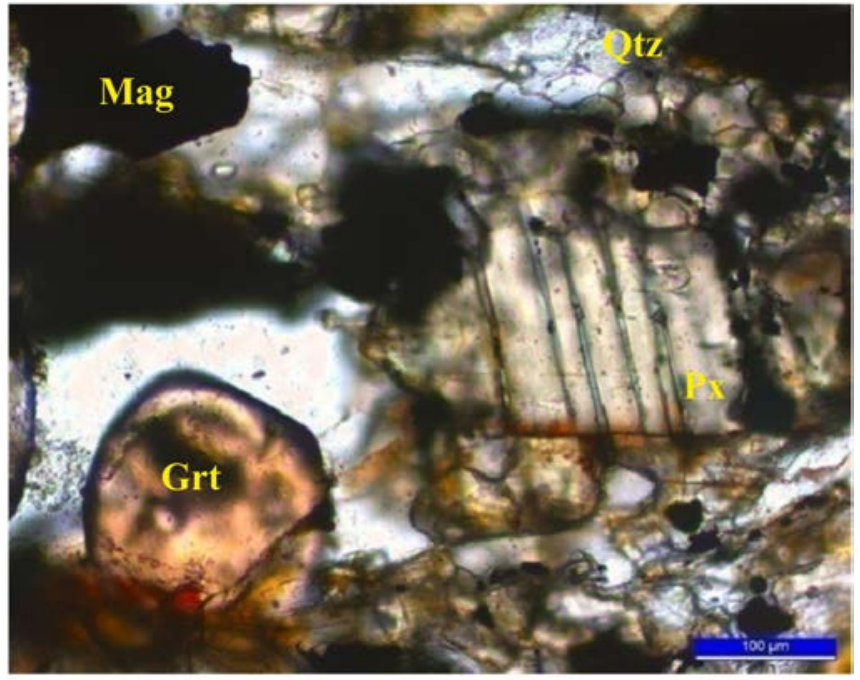

Figure 3. Photomicrograph showing mineral assemblage of highgrade BIF occurring along the BTZ in parts of Paswara area, Mahoba (Grt: Garnet, Mag: Magnetite, Px: Pyroxene, Qtz: Quartz). The exsolution lamelle of Cpx are seen within Opx. The Grt and Px are Mn-rich. 
BIFs of Mesoarchean age show tectonic relation with basic, ultrabasic and felsic volcanic assemblies (Singh and Slabunov, 2016). Also, in the southern part of BuC, it encompasses tectonic contact with TTGs (Singh and Slabunov, 2015). Recently Alfimova et al. (2019) reported the first geochemical and Sm-Nd isotopic data of iron-rich and silica bands from BIFs of BuC and compared them with those from Fennoscandian shield (FS) and East-European Platform (EEP). They compared Algoma type BIFs of BuC and FS with EEP and they observed that $\varepsilon \mathrm{Nd}_{[\mathrm{t}]}$ for silica-rich layers is elevated compared to ironrich layers for all the samples. According to them, despite the diverse spatial disposition of BIFs worldwide, the higher $\varepsilon \mathrm{Nd}_{[t]}$ values $(\sim+5.0)$ in silica-rich layers and lower $\varepsilon \mathrm{Nd}_{[t]}$ values $(-5$ to +2$)$ for iron-rich layers suggest their derivation from juvenile and continental sources, respectively.

\section{White Schists}

Traditionally the rocks of BuC was known to have witnessed greenschist to possibly granulite facies metamorphism (Basu, 1986) till a quartz-free, corona-mantled corundum porphyroblastic, phlogopite + chlorite + clinozoisite-bearing phengite schist (Fig. 4a) occurring within TTG gneisses was discovered (Saha et al., 2011) and this is considered as one of the "spectacular discoveries" (van Hunen and Moyen, 2012) of Archean metamorphism. The KMASH and CKMASH pseudosection modeling suggested that the outer and inner coronae formed at pressures of 18-20 and $12 \mathrm{~kb}$, respectively. This unique assemblage observed in BuC was exhumed along a clockwise P-T path suggesting a Neoarchean subduction event in the north central India and followed by granitoid magmatism in the area.

\section{Calc-silicate rocks}

Calc-silicate rocks are exposed along the BTZ intimately associated with amphibolites, quartzites and BIFs. Excellent exposures are seen in Bhaunti (Fig. 4b; Shivpuri), Mankua (Fig. 4c; Jhansi), Sukwan-Dukwan and Baragaon (Jhansi) with some showing partially developed karst-like topography (WSW of Mankua, Jhansi) and elephant-skin weathering features in the outcrop-scale. They exhibit excellent mm- to cm-thick primary layering and deformed structures. Their mineralogy is similar to marls (amphibole + diopside + quartz + alkali feldspar + apatite \pm calcite \pm wollastonite). They show multiple phases of ductile and brittle deformation while retaining the primary foliation ( \pm with the imprints of possible microbially induced sedimentary structures, MISS) (Pati, 2010).

\section{Quartzites}

The southern part of BuC is mainly composed of BIFs, quartzites,
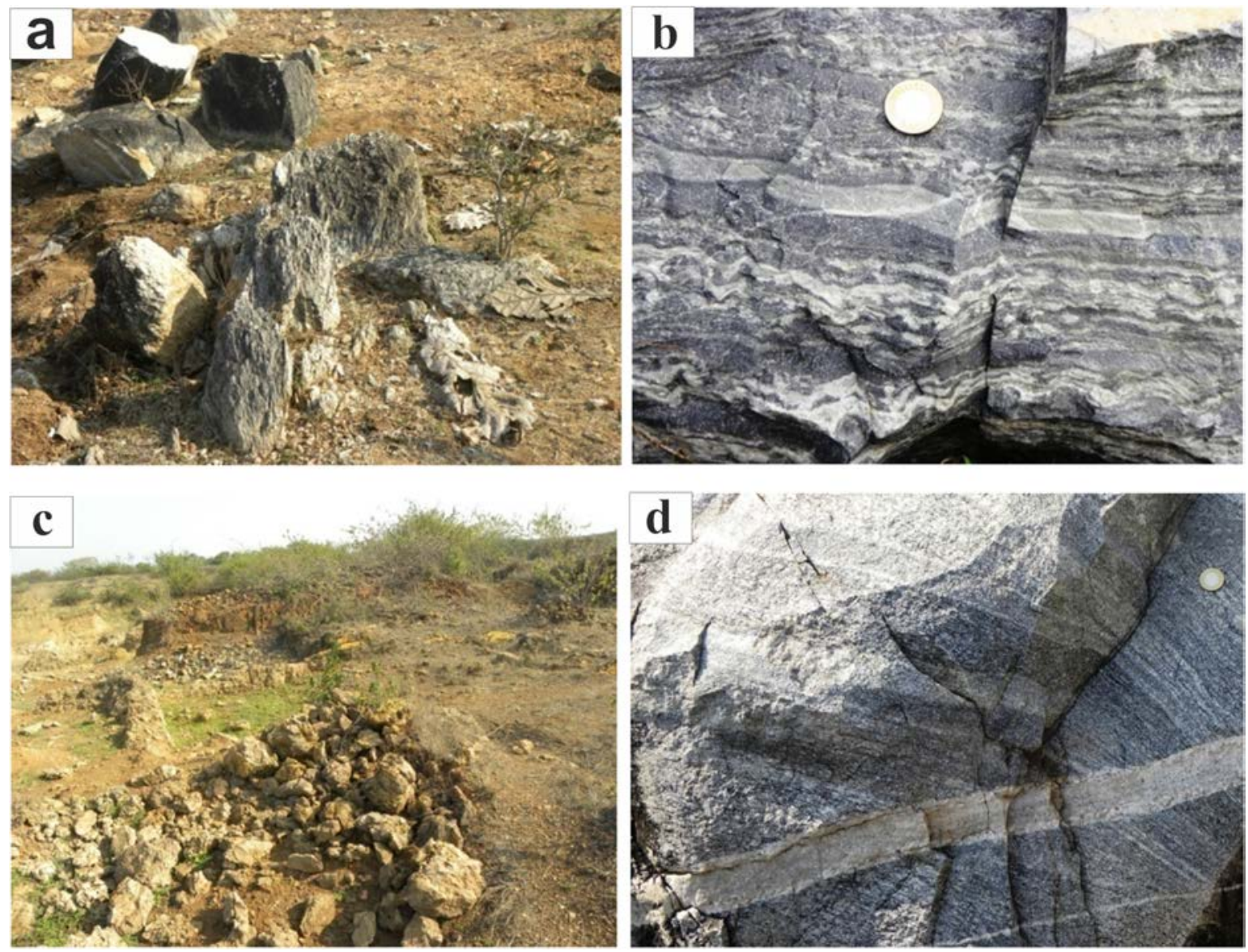

Figure 4. Field photographs showing: a) Quartz-free, corundum-bearing white schist from Chaurara Reserve Forest, SSE of Babina. The outcrop is $2 \mathrm{~m} \times 0.8 \mathrm{~m}$, b) Calc-silicate rock exposed in Bhaunti area, Shivpuri district, Madhya Pradesh. It comprises multiple layers of variable thickness and composition, c) Calc-silicate rocks near Mankua (Babina, Jhansi) showing karst-like topography. d) Tonalitetrondhjemite-granodiorite (TTG) gneiss shows alternating leucocratic and mesocratic layers. A granite pegmatite vein exhibiting grain-size variation is cutting across the gneissosity of the TTG. 
schist, sericite, mafic and ultramafic rocks (Farooqui and Singh, 2006; Singh and Slabunov, 2016; Slabunov et al., 2017; Mohanty et al., 2018; Singh et al., 2019). Here, the thickness of quartzite outcrop is $\sim 300 \mathrm{~m}$ and it is characterized by fuchsite and hematite-bearing quartz arenite with schist and lesser quartz pebble conglomerate (Singh and Slabunov, 2015, 2016). Slabunov et al. (2017) reported trace element data of zircons (3.43-3.25 Ga), separated from samples of these quartzites. They suggested the existence of felsic continental crust in SBuC during Paleoarchean period as inferred by Sm-Nd isotopic data which also shows similarity to the U-Pb zircon data $(\sim 3.43 \mathrm{Ga})$ as well. They also inferred a granitic parent for the genesis of quartzites in Girar area (Slabunov et al., 2017).

\section{Madawara Ultramafic Complex (MUC)}

The MUC lies at the southern fringe of $\mathrm{BuC}$ and has been established as a potential source for platinum group elements (PGEs) in north central India (Pati et al., 2005; Pati et al., 2006; Farooqui and Singh, 2006; Prakash et al., 2009; Farooqui and Singh, 2010; Singh et al., 2011; Balaram et al., 2013; Satyanarayanan et al., 2010, 2014, 2015; Singh et al., 2018). Here, variously altered and metamorphosed ( \pm deformed) mafic and ultramafic rocks (metadunite, metaperidotite ( \pm hornblende), metapyroxenite ( \pm olivine), gabbro and diorite) occur as $\sim \mathrm{E}-\mathrm{W}$-trending lensoidal bodies, distributed in about 400 sq km area and are togetherly, known as MUC (Pati et al., 2005; Farooqui and Singh, 2006; Singh et al., 2011; Satyanarayanan et al., 2014; Mohanty et al., 2018; Ramiz et al., 2018; Singh et al., 2018). An integration of field, petrography and bulk rock geochemistry have been carried out in MUC to understand its petrogenesis and tectonic setting (Mohanty et al., 2018; Ramiz et al., 2018). About $400 \mathrm{~m}$ thick low-lying ridge is the largest outcrop of ultramafic exposed in the south east of Madawara Village (Mohanty et al., 2018). The rocks of this complex are mainly confined between the Madawara Shear in north and the Sonrai-Girar Shear in south and have undergone greenschist to lower amphibolites facies metamorphism (Singh et al., 2010; Satyanarayanan et al., 2014; Ramiz et al., 2018). The whole sequence of mafic-ultramafic rocks of this complex is cut across by dolerite dykes (Singh et al., 2018). In general, the contacts between ultramafic rocks and Bundelkhand granite-gneisses are sheard and mylonitized in the area (Singh et al., 2018; Ramiz et al., 2018). Recent geochemical studies have shown that rocks of this region are enriched in light rare earth elements (LREEs) and LILEs as compared to HREEs and HFSEs favouring the continental arc setting for the MUC (Mohanty et al., 2018; Ramiz et al., 2018). However, Satyanarayanan et al. (2015) have reported that the MUC are depleted in $\mathrm{Cu}, \mathrm{Al}, \mathrm{Ca}$ and $\mathrm{V}$.

\section{Intrusive Granitoids, Syenites and Pegmatites}

The intrusive granitic magmatism (Fig. 5a) in BuC occurred within a time span of about $700 \mathrm{Ma}$ and age of various granitic variants is constrained between 1.9 and $2.58 \mathrm{Ga}$ (Mondal et al., 2002; Pati et al., 2010; Kaur et al., 2016; Verma et al., 2016; Joshi et al., 2017; Singh et al., 2019). The granitoids from BuC are classified on the basis of colour (leuco-, pink and grey granites), texture (aplite, medium- and coarse-grained granites, porphyrytic, rapakivi and orbicular), mineralogy (quartz + feldspar-bearing, biotite granite and hornblende granite), modal types (monzogranite, syenogranite, granite and granodiorite) and based on major oxide data. They show metaluminous to peraluminous chemistry representing a volcanic arc affinity and have a large variation in $\mathrm{SiO}_{2}$ concentration ranging from 49 to 77 wt. \% while the concentrations of $\mathrm{TiO}_{2}, \mathrm{Al}_{2} \mathrm{O}_{3}, \mathrm{Fe}_{2} \mathrm{O}_{3}{ }^{\mathrm{T}}, \mathrm{MnO}, \mathrm{MgO}$, $\mathrm{CaO}$ and $\mathrm{P}_{2} \mathrm{O}_{5}$ exhibit an inverse relationship with $\mathrm{SiO}_{2}$ content (Mondal and Zainuddin, 1996; Ray et al., 2015). They are typically LREE-enriched, HREE-depleted and show negative Eu anomaly with $\mathrm{Ce}_{\mathrm{N}} / \mathrm{Yb}_{\mathrm{N}}$ value ranging from 1.51 to 15.71 and $\mathrm{Gd}_{\mathrm{N}} / \mathrm{Yb}_{\mathrm{N}}$ value from 0.49 to 2.92 (Mondal and Zainuddin, 1996). The K/Rb ratios (95373) exhibit their calc-alkaline nature (Mondal and Zainuddin, 1996). In recent years, several workers have reported major and trace element geochemical data on these granitoids (Ram Mohan et al., 2012; Pati et al., 2014; Ray et al., 2015; Kaur et al., 2016; Joshi et al., 2017; Singh et al., 2019). Based on their geochemical diversity, Joshi et al. (2017) classified them as Low-Silica High-Magnesium (LSHM) granitoids (e.g. sanukitoids and Closepet type granitoids) and HighSilica Low-Magnesium (HSLM) granitoids (e.g. monzogranites with low HREEs and low Eu subgroups). Also, Ray et al. (2015) classified these granitoids into three different categories (pink granitoid; biotite granitoid and grey granitoid) depending upon their distinctive radioelemental (K, Th, U) signatures. Joshi et al. (2017) recognized the existence of sanukitoids in $\mathrm{BuC}$ for the first time and discussed its tectonic setting. These sanukitoids were intruded by high-K granite at several places. In general, the mineralogy of these sanukitoids includes plagioclase, hornblende, biotite and quartz, whereas quartz and K-feldspar are common minerals in high-K anatectic granites with plagioclase, biotite, zircon, apatite, monazite, titanite and allanite occurring as accessories (Singh et al., 2019). According to Joshi et al. (2017) and Singh et al. (2019), the geochemistry of sanukitoids shows high $\mathrm{SiO}_{2}$ (61-71 wt. \%), Mg\# (41-50), Cr (up to $92 \mathrm{ppm}$ ) and $\mathrm{Ni}$ (up to $22 \mathrm{ppm}$ ) with relatively higher concentration of $\mathrm{K}_{2} \mathrm{O}$ (1.984.96 wt. \%), Ba (400-2517 ppm), Sr (184-693 ppm) and ferromagnesian oxides (4.47-11.6 wt. \%). Similar to the high-k anatectic granites, they are also depleted in HFSEs with relatively enriched concentration of LREEs and LILEs compared to HREEs and show negative trend of $\mathrm{Cr}, \mathrm{Ni}, \mathrm{Zr}$ and $\mathrm{Sr}$ with respect to $\mathrm{SiO}_{2}$ (Singh et al., 2019). The high-K anatectic granites are composed of high $\mathrm{SiO}_{2}$ (70-77 wt. \%), $\mathrm{Na}_{2} \mathrm{O}$ (2.93-5.49 wt. \%) and $\mathrm{K}_{2} \mathrm{O}$ (3.62-.18 wt. \%) with relatively less amount of $\mathrm{Al}_{2} \mathrm{O}_{3}$ (12-15 wt. \%), Mg\# (1339), and $\mathrm{TiO}_{2}$ (0.06-0.8 wt. \%) (Singh et al., 2019). The trace element concentrations in these granites are variable for $\mathrm{Ba}$ (51-1437 ppm) and $\mathrm{Sr}$ (19-399 ppm) but it is higher for Th (up to $81 \mathrm{ppm}$ ) compared to sanukitoids. These data resemble that they are formed by partial melting of pre-existing TTG crust at the time of cratonic stabilization (Singh et al., 2019). They also suggested that the mixing of metasomatized mantle melt and anatectic melt pursued by shallowlevel homogenization is responsible for the formation of sanukitoids. The contemporaneous emplacement of these sanukitoids with high$\mathrm{K}$ anatectic granites in the $\mathrm{BuC}$ is supported by several studies (Mondal et al., 2002; Pandey et al., 2011; Kaur et al., 2016; Joshi et al., 2017; Singh et al., 2019). However, syenites are very rare in BuC, occur as intrusive rocks in parts of Lalitpur district and comprise Kfeldspar and hornblende mainly (Malviya et al., 2004, 2006; Pati et al., 2008). Unlike other Indian cratons, the granite pegmatites are volume-wise meagre in BuC. These pegmatites constitute quartz and feldspar, and mostly devoid of hydrous phases. Their width rarely exceeds a metre and show grain size variation (very coarse-grained in the contact to aplitic in the central part). Mineralogical layerings (mafic and felsic) in granitoids are observed in places associated with pegmatites. 


\section{Granite Porphyry}

This hypabyssal rock is very well exposed in parts of Lalitpur district, Uttar Pradesh and comprises euhedral feldspar (invariably zoned and showing sieve-texture at places) and quartz (blue in colour) in an aphanitic felsic groundmass (Fig. 5c). The blue colour in quartz possibly owes its origin to the presence of transition metal elements or caused due to the presence of sub-micron size ilmenites (Seifert et al., 2011). They preserve excellent petrographic signatures of magma hybridization (zoned and sieve-textured feldspars).
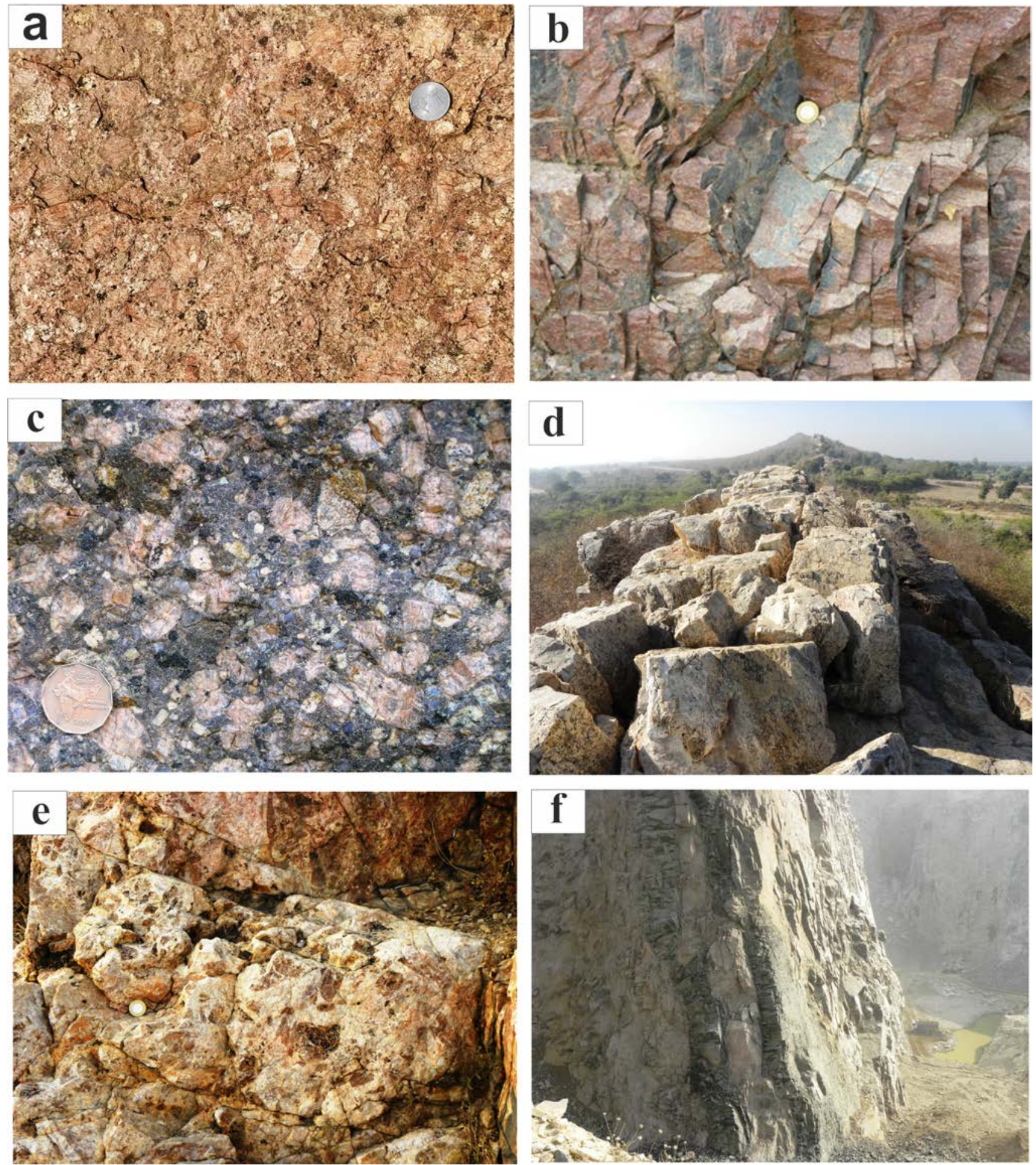

Figure 5. Outcrops exhibiting: a) Coarse-grained pink porphyritic granite showing rapakivi texture and euhedral feldspars exhibit random orientations, b) Pervasively fractured rhyolite exposed in Bansi area, Lalitpur district, Uttar Pradesh, c) Granite porphyry comprising euhedral zoned alkali feldspars and blue quartz in an aphanitic felsic groundmass, d) NNE-SSW trending GQV showing its linear to curvilinear trend with fractured main quartz vein ( $5 \mathrm{~m}$ wide) and colluviums on either flanks, e) Signature of brittle deformation (tectonic breccia) preserved within $G Q V$, f) Subvertical bifurcated mafic dykes cutting across a granodiorite exposed in vertical section of a stone quarry in Kabrai, Mahoba district, Uttar Pradesh. 


\section{Rhyolites}

The $\sim \mathrm{E}$-W-trending rhyolite outcrops are best exposed as small mounds to hills around Jamalpur-Harshpur-Asau, Pura-Bansi, Lalitpur district, Uttar Pradesh. The rocks are pinkish brown coloured, massive, extensively fractured (Fig. 5b) and in places mm- to cm-size quartz vein occur within rhyolites. Euhedral alkali feldspar phenocrysts with or without embayment and reaction rims are observed in a silica-rich groundmass. The feldspar is invariably sericitized. Other secondary phases include epidote, calcite and chlorite. The accessory minerals such as sphene, magnetite, zircon, apatite and monazite are also noted. Rhyolites are also exposed in other parts of BuC, such as Dabiya Gobind and NW of Dhala, Shivpuri district, Madhya Pradesh. The ${ }^{206} \mathrm{~Pb} /{ }^{207} \mathrm{~Pb}$ age of rhyolite from Bansi area $(2517 \pm 7 \mathrm{Ma}$; Mondal et al., 2002) suggests relatively younger age to so-called contemporaneous intrusive felsic magmatism in BuC.

\section{Giant Quartz Veins (GQVs)}

The first comprehensive study of GQVs (Fig. 5d) was reported by Pati et al. (2007). These GQVs occur pervasively as spectacular landforms in the BuC with NNE-SSW to N-S trends and extend up to $60 \mathrm{~km}$ along their strike with exposed width between $\geq 1$ and $\sim 70 \mathrm{~m}$. Very rare exposures of $\sim \mathrm{E}-\mathrm{W}$ and NW-SE oriented GQVs are also known. The silica solution occupies regional scale near vertical faultcontrolled dilational jogs. Fault breccias (Fig. 5e) and subhorizontal stretching lineations are very well preserved in GQVs. They comprise mainly quartz and $<5$ modal $\%$ of \pm sericite, \pm epidote, \pm opaques and \pm calcite. The quartz grains are extensively deformed (Pati et al., 2007). The $\mathrm{SiO}_{2}$ content varies between 84 and 96 wt. \%. The chondrite-normalized REE patterns of GQVs are compared with quartz from granite pegmatite, alkali granite, granodiorite, and migmatite leucosome samples from BuC. All the samples show high LREE $\left(1.83<\mathrm{La}_{\mathrm{n}}<253.13\right)$ and low HREE $\left(0.28<\mathrm{Yb}_{\mathrm{n}}<10.08\right)$ contents. The $\Sigma$ REE values are inversely proportional to the $\mathrm{SiO}_{2}$ contents of the respective samples. The patterns in general show significant $\mathrm{La}_{\mathrm{n}} / \mathrm{Yb}_{\mathrm{n}}$ values (0.79-63.41) and imply slightly fractionated to highly fractionated mode of REE suggesting multiple agents and episodes of silica-rich hydrothermal fluid activity. Also, it displays flat to moderately steep HREE with variable degree of Eu depletion. The REE pattern of GQVs compares very well with that of metamorphic quartz analyzed by Monecke et al. (2002). But the metamorphic quartz has less Sr compared to the vein quartz in BuC and this could be related to the extensive fluid/rock interaction and potash metasomatism. The trace element geochemistry and texture support a hydrothermal origin more prominently. Other than sulphides, GQV has shown significant enrichment of chalcophile elements (Ag, $\mathrm{Sb}, \mathrm{Cd}, \mathrm{Mo}, \mathrm{As}, \mathrm{Sn}$ and $\mathrm{Pb}$ ) having $\mathrm{HREE}_{\mathrm{n}}$ concentration (flat to variable) similar to the earlier reports from hydrothermal vein quartz (Monecke et al., 2002; Pati et al., 2007). Further, the existence of breccia texture in GQV in the outcrop scale, drusy quartz, compositional zoning in mesoscopic scale, the occurrence of large angular granitoid clast within GQVs, and the presence of undulose extinction in the microscopic scale, and defomation lamellae in quartz support a hydrothermal origin (Pati et al., 2007). Earlier, the GQVs of BuC are treated as single physical and chemical entity. Pati et al. (2007) demonstrated the polygenic character of GQVs and the overprinting relationships between hydrothermal and metamorphic processes contrary to the earlier proposed sedimentary and igneous origins for the GQVs. Recent study on the fluid inclusion petrography of the GQVs (Rout et al., 2017) suggests that there are four types of inclusions: 1 . aqueous biphase (type-I), 2. pure carbonic (type-II), 3. aqueous carbonic (type-III) and 4. polyphase (type-IV) inclusions. The type-I aqueous biphase inclusions are the dominant type. The calculated salinity from temperature of melting of last ice (Tm) values are low to moderate, ranging from 0.18 to 18.19 wt. \% $\mathrm{NaCl}$ equivalents. The temperature of liquid-vapor homogenization (Th) data of these inclusions show a wide variation between $101^{\circ} \mathrm{C}$ and $386^{\circ} \mathrm{C}$ (cluster around $150-250^{\circ} \mathrm{C}$ ) essentially into liquid phase ruling out boiling during its course of evolution. Besides, aqueous biphase inclusions, some data on pure $\mathrm{CO}_{2}$ inclusions indicate a near constant value of $\mathrm{T}_{\mathrm{mCO} 2}$ at $-56.6^{\circ} \mathrm{C}$ in $\mathrm{BuC}$ suggesting absence of $\mathrm{CH}_{4}$. Bivariate plot between $\mathrm{Th}$ and salinity suggests three possible water types which are controlling the overall activity of fluid in GQVs of BuC viz. lowT low saline, high-T low saline and moderate-T and moderate saline. A low saline and $\mathrm{CO}_{2}$-bearing phase along with higher temperature nature resembles a metamorphic fluid that could be a source for these GQVs. The low temperature low-salinity component could be a meteoric fluid which possibly mixed with a moderate salinity fluid. Such a moderate salinity fluid could represent a magmatic fluid that evolved to low temperatures through prolonged fluid-rock interaction. It is interesting to note that the fluid characteristics of GQVs compare well with mineralized reefs in the Dharwar and Bastar cratons (Rout et al., 2017). The K-Ar chronological data suggests the GQVs formation between 1.9 and 2.0 Ga (Pati et al., 1997; Pati et al., 2007).

\section{Mafic Dykes}

More than 700 mafic dykes of tholeiitic composition having strike length of up to $\geq 50 \mathrm{~km}$ and width of $\leq 100 \mathrm{~m}$ are exposed as bouldery outcrops with dominant NW-SE trend (Pati et al., 2008b). Occasionally, the dykes show N-S to ENE-WSW and rarely WNWESE orientations (Fig. 5f). The dykes commonly exhibit branching and coalescence patterns similar to GQVs. The dykes occur as mappable, long, discontinuous, linear ridges with moderate relief and are highly jointed. The dykes often show chilled margins. The dykes are dark greenish grey in colour, fine to medium grained with ophitic to sub-ophitic texture and in the marginal portions, intergranular and intersertal textures are mostly observed. The mineralogy includes: plagioclase + clinopyroxene \pm olivine \pm quart \pm ilmenite \pm magnetite. In number of dykes, the effect of retrograde metamorphism, probably due to late stage fluid activity is conspicuous. The resultant phases comprise talc, chlorite and actinolite after olivine and clinopyroxene. Plagioclase is intensely saussuritised. In addition, the other minerals such as chlorite, amphibole, epidote and sphene are also observed. The plagioclase is the dominant mineral (modal average: 45-50\%) closely followed by clinopyroxene (40-48\%). It can be said that crystallization either started with olivine followed by clinopyroxene followed by plagioclase or there was a simultaneous crystallization of clinopyroxene and plagioclase (ophitic texture). They are characterized as subalkaline, hypersthene- to olivine-normative continental tholeiites. They are LREE-enriched $\left((\mathrm{La} / \mathrm{Sm})_{\mathrm{Cn}}=4.65-\right.$ 1.42), HFSE depleted and show variable Eu-anomaly (Eu/Eu*=1.280.68) possibly related to the change in $\mathrm{fO}_{2}$ conditions vis-à-vis variable depths of their emplacement with limited crustal contamination (Pati et al., 2008b). The plume-generated mafic magma was emplaced along the tectonically controlled-extensional fractures (Pati et al., 2008b; 
Mondal and Ahmad, 2008) in a protracted phase between 1.8 and 1.97 Ga (Sarkar et al., 1997; Pradhan et al., 2012).

Radhakrishna et al. (2013) discussed a paleomagnetic perspective on mafic dykes of BuC showing several assemblies with their characteristic remanence and having multiple components: a) ca. 2.37 Ga and 2.45 Ga steep upward/downward, b) ca. 2.18 Ga shallow easterly and antipodal shallow westerly, c) $1.99 \mathrm{Ga}$ shallow northewest and antipodal shallow southeast and d) 2.2 Ga northeast shallow component. This paleomagnetic study on dykes has indicated higher latitudinal values during 2.37-2.45 Ga and an equatorial position between 2.2 and 1.8 Ga period revealing similarity with the Dharwar Craton of India as well as the Yilgarn Craton of Western Australia. It also concluded that the cratonic blocks of Indian shield were in close proximity by about $2.5 \mathrm{Ga}$ (Radhakrishna et al., 2013).

\section{Metamorphism}

The metasupracrustals and felsic intrusives of BuC show distinct signatures of metamorphism which was earlier bracketed between greenschist and granulite facies (Basu, 1986; Singh et al., 2007; Singh and Dwivedi, 2009). The earliest suggested metamorphic event based on Nd isotopic values of amphibolites along the BTZ refers to a model age cluster around 3.4-3.3 Ga (Malviya et al., 2005). The first report of corundum-bearing white schist suggested a high (12 kb) to ultrahigh pressure (18-20 kb) metamorphism of Archean age ( 2.78 Ga) followed by exhumation at $\sim 2.47$ Ga exhibiting a clockwise P-T-t path (Saha et al., 2011). However, the intrusive granitoids are mildly metamorphosed but supracrustals within BTZ record both high Plow $\mathrm{T}$ and high T-low P metamorphism. The amphibolites and BIFs preserve imprints of high pressure and high temperature metamorphism, respectively. Petrographic evidence of exhumation, such as volume expansion cracks are very nicely preserved in some of these metasupracrustals. In addition, the SHRIMP data have shown distinct signatures of Pan-African and Grenvillian Orogenies in BuC (Pati et al., 2010) suggesting at least five temporally distinct metamorphic events between 3.20 and 0.53 Ga (Pati et al., 2010; Saha et al., 2010; Pati and Saha, 2011; Saha et al., 2016; Kaur et al., 2016). Based on geothermobarometry data, it is concluded that rocks of the BuC show high grade metamorphism and equilibrated at pressure-temperature range of 5-6 kbar and $700 \pm 50^{\circ} \mathrm{C}$ (Singh and Dwivedi, 2009). The pseudosection study along gneissic foliation (defined by biotite and hornblende) of TTGs has shown this value varying from $\sim 6.5$ to $8.5 \mathrm{kbar}$ and 600 to $750^{\circ} \mathrm{C}$ (Nasipuri et al., 2019). However, both metasediments and metavolcanics of Bundelkhand correspond to low grade metamorphism with P-T estimates of $4-5$ kbar and $500 \pm 50^{\circ} \mathrm{C}$, respectively.

\section{Tectonic Imprints}

Studies pertaining to structure and tectonics are rare and reported from a few selected domains (Sharma, 1982; Roday et al., 1995; Prasad et al., 1999; Malviya et al., 2006; Nasipuri et al., 2019). Three (Singh et al., 2007) to five phases of folding in TTG gneisses and metasupracrustals have been reported (Sharma, 1982; Prasad et al., 1999) with foliations steeply dipping $\left(60^{\circ}-70^{\circ}\right)$ in north-east or southwest directions. Folding deformation is most conspicuous in BIF, quartzite, calc-silicate rocks and amphibolites. The F1 folds in BIF are tight to isoclinal with sub-vertical S1 schistosity, parallel to $\sim \mathrm{E}$ W-trending F1 axial plane. The F2 folds are developed over S1 schistosity as puckers and the S2 $\| \mathrm{F} 2_{\mathrm{AxPl}}$. The F3 folds in BIF occur as broad warps. About $79 \%$ basin shortening was calculated using folds in BIF. The isoclinal F1 folds showing layer parallel stretching lineation, perpendicular to the hinge line (F1) in quartzites are best exposed in Sukwan-Dukwan Dam site on Betwa River, Jhansi district suggesting their possible formation by flexural slip mechanism. F2 folds in amphibolites are observed in Mauranipur area and are intruded by pink granite (Fig. 6b). For the first time, Senthiappan (1976 and 1981) showed the presence of a $\sim E-W$ trending sinistral shear zone and named it as "Raksa Shear Zone" (RSZ). The presence of a nearly E-W-trending Archean age crustal-scale sinistral tectonic zone (BTZ: Bundelkhand Tectonic Zone) of about 2-10 km thickness extending all along the Bundelkhand craton around $25^{\circ} 15^{\prime}$ latitude was first established on the basis of field observation (Pati, 1998 and 1999) and remote sensing data. All types of petrofabrics indicating brittleductile deformation (Cataclastite-protomylonite-myloniteultramylonite-pseudotachylites) are observed within BTZ (Fig. 6c). In addition, typical modern day ophiolite-like sequence in parts of Mauranipur area (comprising metamorphosed basaltic pillow lava, basaltic komatiite of boninitic affinity, metadunite and metasediments; Malviya et al., 2006) and Neoarchean age corundumbearing white schist in Babina area establish the BTZ to be an Archean age subduction zone. Interestingly, reports of mineralization (gold: Pati et al., 1997; iron: Basu, 1986; base metal: Pati et al., 2007; molybdenite: Pati et al., 2014) from BuC are mainly confined to the BTZ (Fig. 1b).

\section{Dhala Structure-a Bolide Impact Structure in BuC}

The Dhala impact structure (N 2517'59.7" and E 78 ${ }^{\circ}$ '3.1"), a complex structure, has a currently estimated diameter of $11 \mathrm{~km}$ based on field observations and is located in Shivpuri district, Madhya Pradesh, north-central India (Fig. 6d). It was first reported as a cryptovolcanic explosion structure ("cauldron structure"; Jain et al. 2001). Subsequently, the impact origin of the Dhala structure was proposed and confirmed based on the presence of diagnostic evidence of shock metamorphism, specifically the occurrence of shatter cones (Pati et al., 2019), multiple sets of planar deformation features (PDF) in clasts within melt breccia, ballen quartz, checkerboard feldspar, granular zircon, and shock melted lithic clasts (Pati 2005; Pati and Reimold, 2007; Pati et al. 2008a) and recently an impactor component (chondrite or iron meteorite) in the impact melt breccia has been reported based on Ir, Re-Os and ${ }^{187} \mathrm{Os} /{ }^{188} \mathrm{Os}$ data (Pati et al., 2017). The target lithologies are restricted to Archean crystalline basement rocks of the BuC, mainly composed of granitoids of $2563 \pm 6$ Ma age. It is overlain unconformably by post-impact sediments (Dhala Group) followed by Semri Group of the Vindhyan Supergroup (Jain et al., 2001). The impact event is estimated to have taken place between 1700 and 2570 Ma ago (Pati et al. 2010) and the Dhala structure stands as the seventh oldest till date of the 190 confirmed impact structures known worldwide (Earth Impact Database, 2019).

\section{Ore Minerals}

The BuC is considered barren in terms of any major economic mineral deposit (Jhingran, 1958; Basu, 1986) except for pyrophyllite- 
diaspore (Sharma, 1979; Prakash et al., 1975; Pati, 1998), sporadic incidences of gold (Pati et al., 1997), molybdenite (Kumar, 1996; Pati, 1996; Nim and Hassan, 1997; Shukla and Singh, 1997; Pati and Panigrahi, 2005 and 2014), pyrite-chalcopyrite (Pati, 2005), galena (Basu, 1986) and iron deposits (Basu, 1986 and references therein). There are recent reports pertaining to the occurrence of PGE mineralization in mafic-ultramafic rocks disposed in the southern margin of BuC especially in Madaura and Ikonakhurd areas, Lalitpur district, Uttar Pradesh (Pati et al., 2005; Farooqui and Singh, 2006, 2010). The asbestos mineralization occurs in Bargaon area (N2513'52.1"; E79¹0'26.7"), Mauranipur, Jhansi district, U.P. (Fig. $6 e$ ) and the mineralization is associated with mafic-ultramafic rocks occurring over an area of about 2 sq km representing a part of the Archean ophiolite sequence (type I; Ross, 1981).
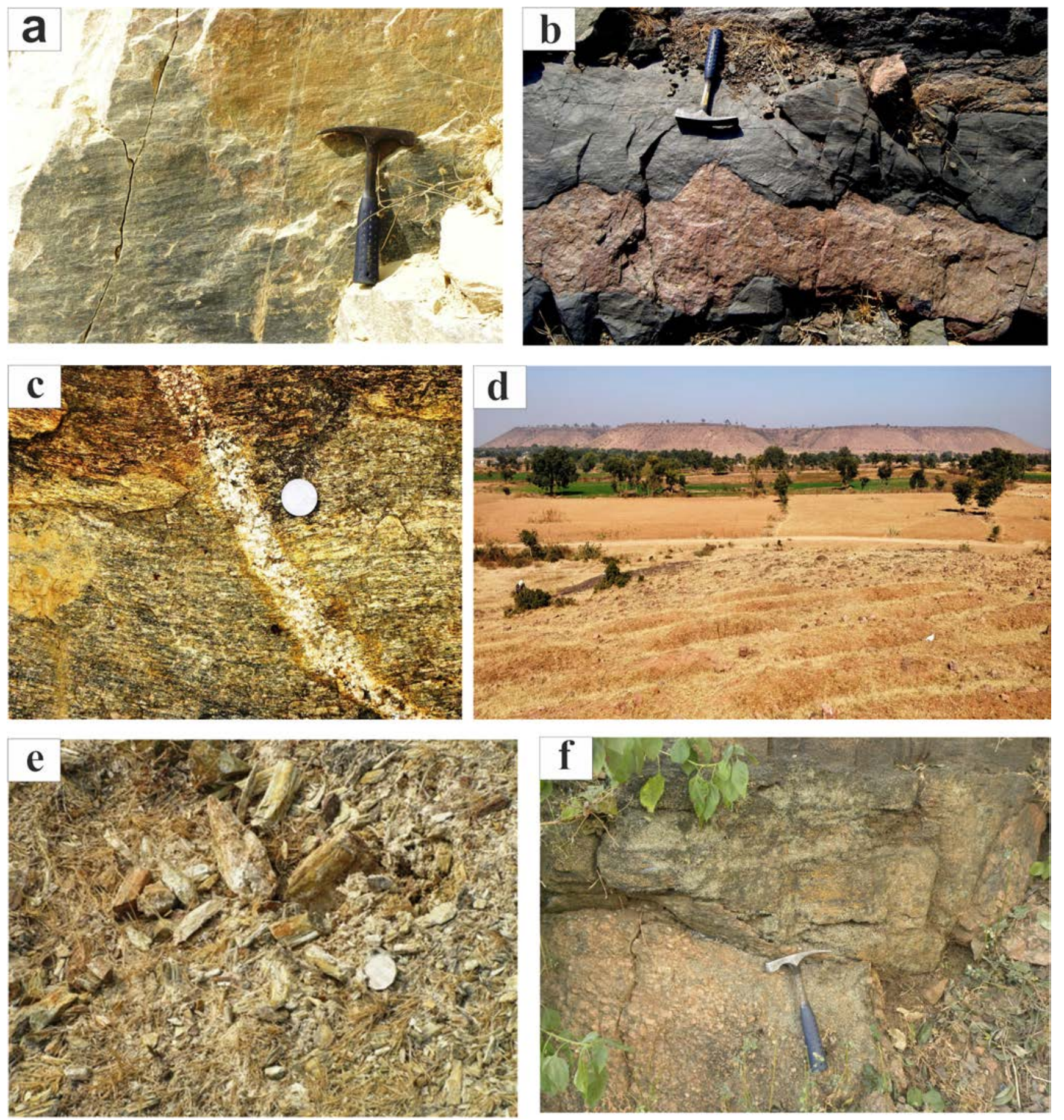

Figure 6. Field images pertaining to: a) Subhorizontal stretching lineation in a granodiorite along the BTZ, b) Folded amphibolite is intruded by pink granite observed in parts of Mauranipur area, $c$ ) Mylonitic fabric in a granitoid dissect granite pegmatite suggesting the ductile deformation post-dates the last phase of felsic magmatism known till date, d) Central Elevated Area (CEA) exposed as a mesa-like feature in Dhala impact structure and the monomict breccia outcrop occur in the foreground, e) Asbestos (light yellow in colour) outcrops are associated with metamorphosed ultramafic rocks in Bargaon area of Mauranipur, Jhansi (U.P., India), f) The coarse-grained pink porphyritic granitoid ( 2550 Ma; BuC) is unconformably overlain by sedimentary rocks (Vindhyan Supergroup). 


\section{Features Unique to Bundelkhand Craton}

The $\mathrm{BuC}$ is unique in many ways unlike other Archean cratons of India. The most puzzling observation, based on available geochronological data till date, relates to hitherto known time gaps between some of the major lithounits. The various TTG gneisses record a time interval of about $900 \mathrm{Ma}$, available chronological data of granitoids indicate a time gap $\sim 700 \mathrm{Ma}$ and a hiatus of about $900 \mathrm{Ma}$ is noted between the oldest dated cover sediments (Vindhyan Supergroup) and underlying Bundelkhand granitoids (Pati et al., 2010 and the references therein; Fig. 6f). There are several textural and chemically distinct granitoids yet pegmatites are very rare and generally devoid of hydrous phases. Tourmaline is a very important accessory mineral indicating boron metasomatism of granitic magma which is frequently observed in granitoids from the adjoining Aravalli Craton, Chhotanagpur Gneissic Complex and Bastar Craton. However, tourmaline is conspicuously absent in Bundelkhand granitoids and this puts an excellent constraint on the source provenance of tourmaline-bearing sedimentary rocks observed in the peripheral basins. The BuC lacks economic mineral deposits barring pyrophyllite-diaspore despite having voluminous silico-thermal deposits in the form of GQVs. Two temporally independent, diagonal (NNE-SSW and NW-SE mainly), mappable, pervasive, crustal-scale, tensile stress-generated tectonic fabric elements occur within the BuC and are occupied by silica-saturated fluids and tholeiitic magma, respectively during post-stabilization of Bundelkhand cratonic crust. The GQVs are emplaced along vertical faults recording extensive brittle-ductile deformation signatures whereas mafic dykes show only extensional fractures mostly perpendicular to their strike trend. In addition to an Archean age subduction zone, the BuC also preserves unequivocal evidences of a Paleoproterozoic meteoritic impact event (Dhala structure; Pati et al., 2008a; Pati et al., 2017).

\section{Geodynamic evolution in space and time}

The BuC, like other Archean cratons of India and other parts of the world, comprises TTG gneissic complexes, extensively deformed greenstone belts, polymetamorphosed domains, intracratonic sediments and mobile belt. Earlier the BuC was considered as a batholith similar to Sierra Nevada and granitoids believed to have formed in a northward subduction-related tectonic setting. The detailed mapping provided evidence for a crustal-scale tectonic zone (BTZ; Pati et al., 1997; Pati, 1999) in the central part of the BuC. Then, the report of basaltic pillow lava from Mauranipur area in a subductionrelated tectonic setting of Archean age (Malaviya et al., 2006) and very high pressure metamorphism (up to $20 \mathrm{~kb}$; Saha et al., 2011) from Babina area revolutionized the understanding of the BuC. The field and petrographic evidences are now very well supported by geophysical data (Gokarn et al., 2013; Mandal et al., 2018; Nabakumar and Kumar, 2018) indicating the existence of the BTZ. The Bouguer gravity anomaly map of the Bundelkhand Craton clearly divides the craton into a gravity low (Southern BuC) and relatively gravity high (northern BuC) domains on either side of BTZ (Fig. 7). The depth to the Moho in BuC also increases from N to S (Singh et al., 2017). Based on available geochronological data so far, the age of various granitoids (excluding the BTZ) shows a decrease from north to south

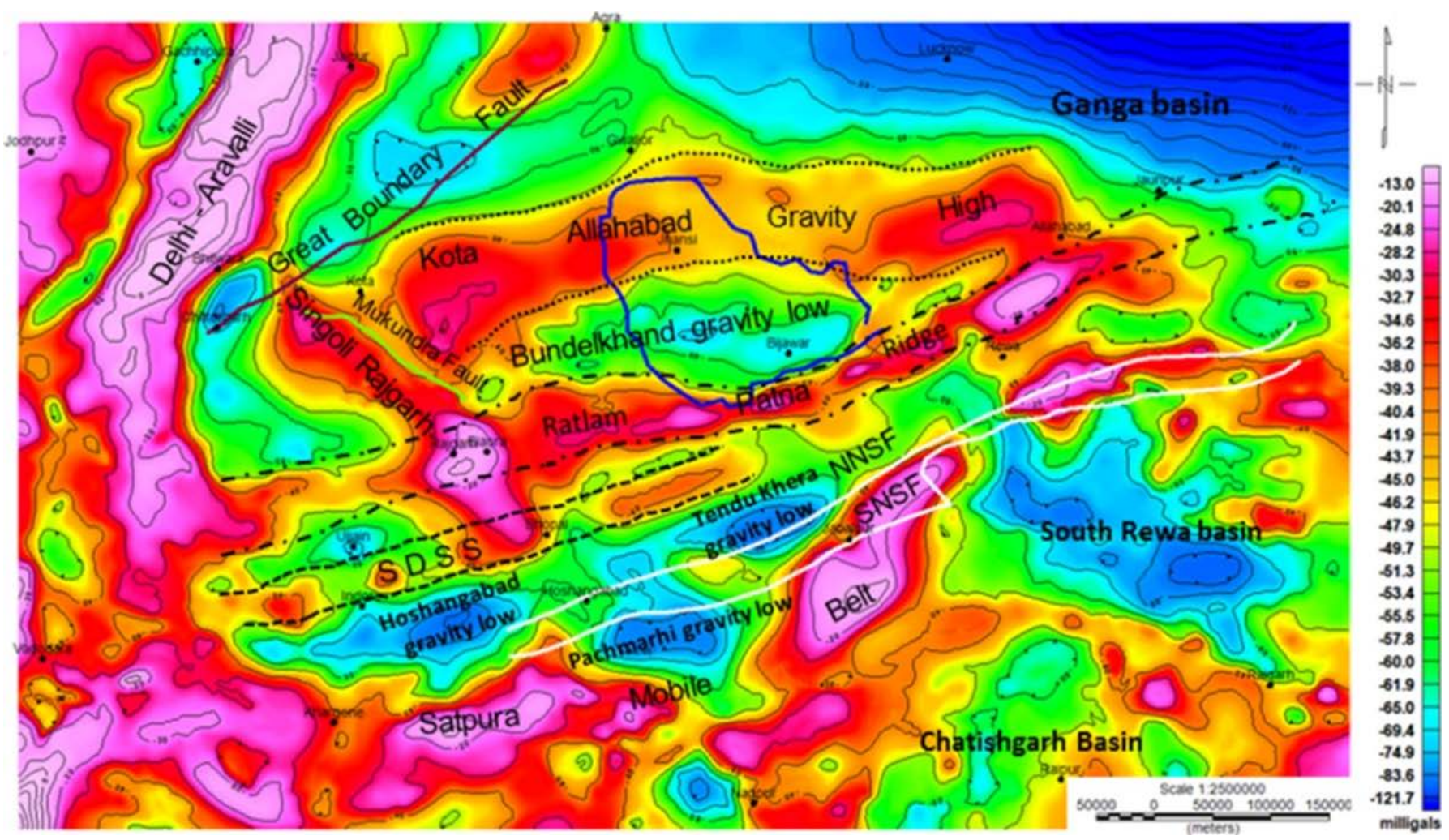

Figure 7. Bouguer gravity anomaly map (after Nabakumar and Kumar, 2018) shows the areal extent of Bundelkhand craton (BuC) marked by solid blue line. This map clearly shows two distinct domains of gravity low (Southern BuC) and gravity high (northern BuC). The line that divides two domains clearly coincides with the BTZ (Pati, 1999). In the southern fringe of the BuC, the increase in gravity value results because of the ultramafic rocks of Madaura/Madawara area. 
in BuC, except few samples of SBuC (Talbehat: $2544 \pm 3$ Ma and Lalitpur: $2564 \pm 42$ Ma, Kaur et al., 2016; Joshi et al., 2017). The Karera Gneiss ( $2563 \pm 6 \mathrm{Ma}$ ) and the SHRIMP U-Pb zircon age from Dhala area corresponding to basement granitoid provides a corcordant age of $2552 \pm 6$ Ma (Mondal et al., 2002; Pati et al., 2007; Saha et al., 2010). Both occur to the north of BTZ. In general, the age of granitoids decrease due south of BTZ (Bansi: $2517 \pm 7$ Ma; Datia: $2515 \pm 5$ Ma; Lalitpur: $2521 \pm 5$ Ma; Lalitpur leucogranite: $2492 \pm 10 \mathrm{Ma}$ ). Similarly, the granitoids to the north of BTZ are more intensely deformed compared to those exposed to the south. Hence, the available field, petrological, geochronological and geophysical data suggest that the BuC formed due to the accretion of NBuC and SBuC along the BTZ during the Archean time. However, the TTG basement of BuC occurring along the BTZ has evolved in multiple magmatic events (between 3.55 and $3.20 \mathrm{Ga}$ ) in a subduction-related tectonic setting (Malviya et al., 2005; Malviya et al., 2006; Saha et al., 2010; Kaur et al., 2016 Saha et al., 2016 and Chauhan et al., 2018). The available chemical data suggests that the partial melting of hydrated metabasalts (amphibolites) under specific pressures and depths (where garnets and amphiboles were stable) possibly resulted in the formation of TTG magma in a subduction-related tectonic setting (Ram Mohan et al., 2012; Joshi et al., 2017; Chauhan et al., 2018). The granitic magmatism (1.9 and 2.58 Ga; Mondal et al., 2002; Pati et al., 2010; Kaur et al., 2016) of dominantly calc-alkaline affinity formed in a subduction-related tectonic setting also suggests a varied temporal evolution with minor petrographic and geochemical evidences of magma hybridization. Saha et al. (2016) inferred that the BuC is a part of the Ur supercontinent based on similar Paleoarchean temporal evolution of the Bundelkhand, Bastar and Singhbhum Cratons. They revealed that the formation of cratonic crust in the BuC initiated during the same time period of continental crust formation throughout the world. The geochemical data with relatively higher concentration of HFSEs (Nb, Ta and Th etc.) and Nd isotopes and negative epsilon values (-3.64 to -1.66$)$ provided evidences for hybridization and inferred the mixing of anatectic melt with an enriched mantle source (Kaur et al., 2016; Singh et al., 2019). This mixing between mantle and crustal sources is responsible for the origin of LSHM granitoids (sanukitoids and Closepet granitoids) according to Joshi et al. (2017). At the same time, Ramiz and Mondal (2017) proposed negligible to no mixing between granitoid melts (enriched in $\mathrm{K}$ and $\mathrm{Rb}$ ) and mafic magmatic enclaves (enriched in $\mathrm{Ni}, \mathrm{Cr}, \mathrm{Co}$ and $\mathrm{V}$ ) of the BuC. These enclaves have lower concentration of $\mathrm{Rb}, \mathrm{Sr}$, Ba and $\mathrm{K}$ as compared to the granitoids. Presence of plagioclase crystals across the contact boundary is one of the most common evidence of mixing reported by Ramiz and Mondal (2017). Deb and Bhattacharya (2018) suggested that chemical analysis should also be supported by meso- and microscale textural evidences to confirm the signature of magma mixing. They reported acicular apatite, titanite-plagioclase ocelli, ophiticsubophitic texture, mafic clots, resorbed plagioclase, hornblendezircon asscociation and cuspate-lobate boundary along the contact of granitoid and mafic magma which confirm the magmatic mixing in the BuC. Moreover, they have carried out crystal distribution study and revealed concave up curves advocating mixing.

A pervasive ductile deformation event in the form of mylonite zone is best preserved in granitoids on either side of the BTZ predating the emplacement of the GQVs (Fig. 6c). The development of two temporally distinct diagonal sets (NNE-SSW and NW-SE) of tensile fractures possibly developed either due to rotation of principal axis of stress or of the landmass during the Paleoproterozoic time.
The silica-rich fluid activity filled the NNE-WSW-trending faultbound tensile fractures in multiple phases between 1.9 and $2.1 \mathrm{Ga}$. The sealing of the fractures possibly led to the strain build-up in lower crust and the rising plume released substantial heat to promote fractures. The decompression, in turn, led to the lowering of primitive magma liquidus and its viscosity, resulting in tholeiitic magmatism between 1.8 and $2 \mathrm{Ga}$ along the tectonically controlled NW-trending fractures with minimal crustal contamination due to lowering of ambient temperature. However, the BuC continued to remain seismotectonically active and the occurrence of large volume pseudotachylites (>1600 Ma) dissecting granitoids and mafic dykes are often observed. The sediments belonging to Vindhyan Supergroup ( 1600 Ma), Bijawar Group and Gwalior Group unconformably overlie the magmatic rocks of the BuC, mostly exposed in the peripheral basins.

In the last two decades sizeable data on various aspects of $\mathrm{BuC}$ have been generated and they mainly pertain to improved geochronological database of felsic magmatic and metamorphic events, report of a modern day-like ophiolite sequence of Archean age based on field and petrochemical studies, a Neoarchean high pressure (20 kb) - low temperature $\left(\sim 640^{\circ} \mathrm{C}\right)$ metamorphic event along with evidences of Grenvillian and Pan-African imprints, the recognition of multiple litho-tectonic domains within the $\mathrm{BuC}$ which accreted during Meso-to Neoarchean times, and the confirmed presence of a meteoritic impact structure on a crystalline basement of Paleoproterozoic or older age. However, there is a greater need to generate field-based data, rigorous petrographic study, detailed mineralogy and isotopic data of various rock types in the BuC. It is high time to synthesize all the available field data to prepare a detailed geological map of the BuC. It is imperative to understand the spatiotemporal evolution of the GQVs and mafic dykes focusing on the interplay between tectonism, the fluids of the Earth's crust and mafic magmatism in the in BuC.

\section{Acknowledgement}

JKP thanks Professor N.C. Pant for his invitation to contribute to this special volume.

\section{References}

Acharyaa, S.K., Gupta, A. and Orihashi, Y., 2010, New U-Pb zircon ages from Paleo-Mesoarchean TTG gneissesof the Singhbhum Craton, Eastern India. Geochemical Journal, v. 44, pp. 81-89.

Alfimova, N., Raza, M.B., Felitsyn, S., Matrenichev, V., Bogomolov, E., Nasipuri, P., Saha, L., Pati, J.K. and Kumar, V., 2019, Isotopic Sm-Nd signatures of Precambrian Banded Iron Formation from the Fennoscandian shield, East-European Platform, and Bundelkhand craton, India. Precambrian Research, v. 328, pp. 18.

Balaram, V., Singh, S.P., Satyanarayanan, M. and Anjaiah, K.V., 2013, Platinum group elements geochemistry of ultramafic and associated rocks from Pindar in Madawara Igneous Complex, Bundelkhand massif, Central India. Journal of Earth System Science, v. 122, pp. 79-91.

Bandyopadhyay, P.K., Chakrabarti, A.K., Deomurari, M.P. and Misra, S. 2001, 2.8 Ga old anorogenicgranite-acid volcanic association from western marginof Singhbhum-Orissa craton, eastern India.Gondwana Research, v. 4, pp. 465-475.

Basu, A.K., 1986, Geology of parts of the Bundelkhand Granite 
Massif, Central India. Record Geological Survey of India, v. 117, pp. 61-124.

Beckinsale, R.D., Drury, S.A. and Holt, R.W., 1980, 3300-Myr old gneisses from the South Indian Craton. Nature, v. 283, pp. 469470.

Bhattacharya, A.R. and Singh, S.P., 2013, Proterozoic crustal scale shearing in the Bundelkhand massif with special reference to quartz reefs. Journal of Geological Society of India, v. 82, pp. 474-484.

Choudhuri, T., Wan, Y., Mazumder, R., Ma, M., and Liu, D., 2018, Evidence of Enriched, Hadean Mantle Reservoir from 4.2-4.0 Ga zircon xenocrysts from Paleoarchean TTGs of the Singhbhum Craton, Eastern India. Scientific Reports, v. 8(1):7069.

Chauhan, H., Saikia, A., and Ahmad, T., 2018, Episodic crustal growth in the Bundelkhand craton of central India Shield: Constraints from petrogensis of the Tonalite- Trondhjemite-Granodiorite gneisses and K-rich granites of Bundelkhand Tectonic Zone. Journal of Earth System Science, v. 127, pp. 1-34.

Deb, T. and Bhattacharya, T., 2018, Interaction between felsic granitoids and mafic dykes in Bundelkhand Craton: A field, petrographic and crystal size distribution study. Journal of Earth System Science, v. 127:102, pp. 1-14.

Earth Impact Database, 2019. http://www.passc.net/EarthImpact Database/index.html [accessed 10th January 2019].

Farooqui, S.A. and Singh, A.K., 2006, Platinum mineralization in Ikauna area, Lalitpur district, Uttar Pradesh. Journal of Geological Society of India, v. 68, pp. 582-584.

Farooqui, S.A. and Singh, P. K., 2010, PGE mineralisation in ultramafic/mafic enclaves of Ikauna area, Bundelkhand craton, India. In: Satake, K. (Eds.), Solid Earth, Advances in Geosciences, World Scientific Publishing Company, v. 20, pp.111-120.

Ghosh, J.G., 2004, 3.56 Ga tonalite in the central part ofthe Bastar craton, India: oldest Indian date. Journal of Asian Earth Science, v. 23, pp. 359-364.

Gokaran, S.G., Rao, C.K., Selvaraj, C., Gupta, G., Singh, B.P., 2013, Crustal evolution and tectonics of the Archean Bundelkhand craton, Central India. Journal Geological Society of India, v. 82, pp. 455-460.

Goodwin, A.M., 1991, Precambrian Geology: The Dynamic Evolution of the Continental Crust, Academic Press, London, 666 p.

Gopalan, K., Macdougall, J.D., Roy, A.B. and Murali, A.V., 1990, Sm-Nd evidence for 3.3 Ga old rock inRajasthan, north-western India. Precambrian Research, v. 48, pp. 287-297.

Goswami, J.N., Misra, S., Wiedenback, M., Ray, S.L. and Saha, A.K., 1995, 3.55 Ga-old zircon from Singhbhum-Orissa Iron Ore craton, eastern India. Current Science, v. 69, pp. 1008-1011.

Hussain, M.F., Mondal, M.E.A. and Ahmad, T., 2004, Geodynamic evolution and crustal growth of the central Indian Shield: Evidence from geochemistry of gneisses and granitoids. Proceedings of the Indian National Academy of Science, v. 113, pp. 699-714.

Jain, S.C., Gaur, V.P., Srivastava, S.K., Nambiar, K.V. and Saxena, H.P., 2001, Recent find of a cauldron structure in Bundelkhand craton. Geological Survey of India, Special Publication, 64, pp. 289-297.

Jayananda, M., Moyen, J.-F., Martin, H., Peucat, J.-J., Auvray, B. and Mahabaleswar, B., 2000, Late Archean (2550-2520 Ma) juvenile magmatism in the Eastern Dharwar craton, southern India: constraints from geochronology, Nd-Sr isotopes and whole rock geochemistry. Precambrian Research, v. 99, pp. 225-254.

Jayananda, M., Kanob, T., Peucat, J.-J. and Channabasappa, S., 2008, 3.35 Ga komatiite volcanism in the western Dharwar craton, southern India: constraints from $\mathrm{Nd}$ isotopes and whole rock geochemistry. Precambrian Research, v. 162, pp. 160-179.

Jhingran, A.G., 1958, The problem of Bundelkhand granites and gneisses. Presidential Address, Section Geology and Geography. Proceedings $45^{\text {th }}$ Indian Science Congress, Madras, India.

Joshi, K.B., Bhattacharjee, J., Rai, G., Halla, J., Ahmad, T., Kurhila, M.I., Heilimo, E. and Choudhary, A.K., 2017, The diversification of granitoids and plate tectonic implications at the ArchaeanProterozoic boundary in the Bundelkhand craton, Central India. In: Halla, J., Whitehouse, M.J., Ahmad, T., Bagai, Z. (Eds.), CrustMantle Interactions and Granitoid Diversification: Insights from Archaean Cratons. Geological Society of London, Special Publications, 449, pp. 123-157.

Kaur, P., Zeh, A. and Chaudhri, N., 2014, Characterisation and U$\mathrm{Pb}-\mathrm{Hf}$ isotope record of the $3.55 \mathrm{Ga}$ felsic crust from the Bundelkhand craton, northern India. Precambrian Research, v. 255, pp. 236-244.

Kaur, P., Zeh, A., Chaudhri, N. and Eliyas, N., 2016, Unravelling the record of Archaean crustal evolution of the Bundelkhand Craton, northern India using U-b zircon-monazite ages, Lu-Hf isotope systematics, and whole rock geochemistry of granitoids. Precambrian Research, v. 281, pp. 384-413.

Krishnaswamy, S., 1979, India’s Mineral Resources, Oxford and IBH Publishing Company, New Delhi, 658 p.

Kumar, G., 2005, Geology of Uttar Pradesh and Uttaranchal. Geological Society of India Text Book Series, Bangalore, 384 p.

Kumar, S., Raju, S., Pathank, M., and Pandey, A., 2010, Magnetic susceptibility mapping of felsic magmatic lithounits in the central part of Bundelkhand massif, central India. Journal of the Geological Society of India, v. 75, pp. 539-548.

Kumar, S., Bora, S., Raju, S., Yi, K., Pathak, M., Kim, N., and Lee, T.H., 2013, Crustal evolution of Bundelkhand Craton: Constrains from whole rock geochemistry and U-Pb SHRIMP zircon chronology. In: Singh, V.K., and Chandra, R. (Eds.), International association for gondwana research conference, 3rd International conference precambrian continental growth and tectonism: Jhansi, India, pp. 89-90.

Kumar, V., 1996, Possibilities of molybdenite in district Lalitpur. Mineral Resources and Environment: A Special Publication on Bundelkhand. Department of Geology and Mines and State Mineral Development Corporation, U.P., pp. 84-85.

Maibam, B., Goswami, J.N. and Srinivasan, R., 2011, Pb-Pb zircon ages of Archean metasediments and gneisses from the Dharwar craton, southern India: implicationsfor the antiquity of the eastern Dharwar craton. Journal of Earth System Sciences, v. 120, pp. 643-661.

Malviya, V.P., Arima, M., Pati, J.K. and Kaneko, Y., 2004, First report of metamorphosed basaltic pillow lava from central part of Bundelkhand craton, India: An Island arc setting of possible Late Archean age. Gondwana Research, v. 7, pp. 1338-1340.

Malviya, V.P., Arima, M. and Pati, J.K., 2005, Subduction related Archean mafic volcanism from Bundelkhand greenstone belt, Bundelkhand craton, Central India-A geochemical appraisal. The Japanese Association of Mineralogists, Petrologists and Economic Geologists. Annual Meeting, Abstract No. G4P-16.

Malviya, V.P., Arima, M., Pati, J.K. and Kaneko, Y., 2006, Petrology and geochemistry of metamorphosed basaltic pillow lava and basaltic komatiite in Mauranipur area: Subduction related volcanism in Archean Bundelkhand craton, Central India. Journal of Mineralogical and Petrological Sciences, Japan, v. 101, pp. 199-217.

Malviya, V.P., Arima, M. and Pati, J.K., 2013, Petrochemical and geochemical study of Banded Iron Formation (BIF) from Archaean Greenstone Belt of Bundelkhand craton. $3^{\text {rd }}$ Precambrian Continental Growth and Tectonism, 2013, Jhansi, India, Abstract volume International Association for Gondwana Research Conference Series, v. 16, pp. 99-100. 
Mandal, B., Vaidya, V. R., Sen, M. K., Periyasamy, K. and Sarkar, D., 2018, Common reflection surface stack ima-ging of the Proterozoic Chambal Valley Vindhyan basin and its boundary fault in the northwest India: Constraints on crustal evolution and basin formation. Tectonics, v. 37, pp. 1393-1410.

Manglik, A., Adilakshmi, L., Suresh, M. and Thiagarajan, S., 2015, Thick sedimentary sequence around Bahraich in the northern part of the central Ganga foreland basin. Tectonophysics, v. 653, pp. 33-40.

Meen, J.K., Rogers, J.J.W. and Fullagar, P.D., 1992, Lead isotopic composition in the western Dharwar Craton, southern India: evidence for distinct middle Archaean terrains in a late Archaean craton. Geochimica Cosmochimica Acta, v. 56, pp. 2455-2470.

Meert, J.G., Pandit, M.K., Pradhan, V.R., Banks, J., Sirianni, R., Stroud, M., Newstead, B. and Gifford, J., 2010, Precambrian crustal evolution of Peninsular India: A 3.0 billion year odyssey. Journal of Asian Earth Sciences, v. 39, pp. 483-515.

Meert, J. G. and Pandit, M. K., 2015, The Archean and Proterozoic history of Peninsular India: tectonic framework for Precambrian sedimentary basins in India. In: Mazumder R. and Eriksson P. G. (Eds.), Precambrian Basins of India: stratigraphic and tectonic context, Geological Society, London, Memoirs, v. 43, pp. 29-54.

Mishra, S., Deomurari, M.P., Wiedenbeck, M., Goswami, J.N., Ray, S. and Saha, A.K., 1999, ${ }^{207} \mathrm{~Pb} /{ }^{206} \mathrm{~Pb}$ zircon ages and the evolution of the Singhbhum Craton, eastern India: an ion microprobe study. Precambrian Research,v. 93, pp. 139-151.

Mohanty, N., Singh, S.P., Satyanarayanan, M., Jayananda, M., Korakoppa, M.M., Hiloidari, S., 2018, Chromian spinel compositions from Madawara ultramafics, Bundelkhand Craton: Implications on petrogenesis and tectonic evolution of the southern part of Bundelkhand Craton, Central India. Geological Journal, pp. 1-25.

Mondal, M.E.A. and Ahmad, T., 2001, Bundelkhand mafic dykes, Central Indian shield: implications for the role of sediment subduction in Proterozoic crustal evolution. Island Arc, v. 10 (1), pp. 51-67.

Mondal, M.E.A., Goswami, J.N., Deomurari, M.P., Sharma, K.K., 2002, Ion microprobe ${ }^{207} \mathrm{~Pb} /{ }^{206} \mathrm{~Pb}$ ages of zircon from the Bundelkhand massif, northern India: Implication for crustal evolution of Bundelkhand-Aravalli protocontinent. Precambrian Research, v. 117, pp. 85-100.

Mondal, M.E.A. and Zainuddin, S.M., 1996, Evolution of the Archean-Palaeoproterozoic Bundelkhand massif, central Indiaevidence from granitoid geochemistry. Terra Nova, v. 8, pp. 532539.

Monecke, T., Kempe, U. and Götze, J., 2002, Genetic significance of the trace element content in metamorphic and hydrothermal quartz: a reconnaissance study. Earth and Planetary Science Letters, v. 202, pp. 709-724.

Mukhopadhyay, J., Beukes, N.J., Armstrong, R.A., Zimmermann, U., Ghosh, G. and Medda, R.A., 2008, Dating the oldest Greenstone in India, a 3.51-Ga precise U-Pb SHRIMP zircon age for Dacitic Lava of the Southern Iron Ore Group, Singhbhum Craton. Journal of Geology, v. 116, pp. 449-461.

Nabakumar, Kh. and Kumar, S, 2018, Delineation of basement configuration of Chambal and Son valleys in Vindhyan Basin. Geohorizons, pp. 21-26.

Naqvi, S.M. and Rogers, J.J.W., 1987, Precambrian Geology of India, Oxford University Press, London, Inc.. 223 p.

Nasipuri, P., Saha, L., Hangqiang, X., Pati, J.K., Satyanaryanan, M., Sarkar, S., Bhandari, A. and Gaur, Y., 2019, Paleoarchean Crustal Evolution of the Bundelkhand Craton, North Central India. In: Earth’s Oldest Rocks, Elsevier, B.V., chapter 31, pp. 793-817.

Nim, S.P. and Hassan, S.S., 1997, Specialized thematic studies of
Bundelkhand Granitoids for appraisal of the mode of occurrence of molybdenum and associated mineralization, Rauli Kalyanpur area, Banda districts, U.P. Geological Survey of India Records, v. 129, pt. 8, pp. 142-144.

Nutman, A.P., Chadwick, B., Ramakrishnan, M. and Viswanatha, M.N., 1992, SHRIMP U-Pb ages of detrital zircon in Sargur supracrustal rocks in western Karnataka, Southern India. Journal of the Geological Society of India, v. 39, pp. 367-374.

Nutman, A.P., Chadwick, B., Krishna Rao, B. and Vasudev, V.N., 1996, SHRIMP U-Pb zircon ages of acid volcanic rocks in the Chitradurga and Sandur Groups and granites adjacent to Sandur schist belt. Journal of the Geological Society of India, v. 47, pp. 153-161.

Prakash, K., Pati, J.K. and Bhusan, R., 2009, Study of the PGE-bearing mafic-ultramafic rocks of Madaura area, Bundelkhand craton, central India using remote sensing data, $6^{\text {th }}$ International Symposium on Digital Earth, Beijing, China.

Prakash, R., Swarup, P. and Srivastava, R.N., 1975, Geology and mineralization in the southern part of Bundelkhand in Lalitpur district, U.P. Journal of Geological Society of India, v. 16, pp. 143-156.

Pandey, U.K., Bhattacharya, D., Sastry, D.V.L.N., Pandey, B.K., 2011, Geochronology $\mathrm{Rb}-\mathrm{Sr}, \mathrm{Sm}-\mathrm{Nd}$ and $\mathrm{Pb}-\mathrm{Pb}$, isotope geochemisty and evolution of the granites and andesites hosting Mohar Cauldron, Bundelkhand Granite Complex, Shivpuri district, Central India. Exploration Research on Atomic Minerals, v. 21, pp. 103-116.

Pati, J.K., 1996, Report on specialized thematic mapping of Bundelkhand Granites for appraisal of the mode of occurrence of molybdenum and associated minerals, Rauli Kalyanpur-Manpur area, Banda districts, U.P. Progress Report (FSP 1994-1995), Geological Survey of India (NR), 82 p. (Unpublished).

Pati, J.K., 1997, Specialized thematic studies of Bundelkhand Granitoids for appraisal of the mode of occurrence of molybdenum and associated mineralization, Rauli Kalyanpur area, Banda districts, U.P. Geological Survey of India Records, v. 129, pt. 8, pp. 144-146.

Pati, J.K., Raju, S., Mamgain, V.D. and Shankar, R., 1997, Gold mineralisation in parts of Bundelkhand Granitoid Complex (BGC). Journal of Geological Society of India, v. 50, pp. 601606.

Pati, J.K., 1998, Final Report on the study of quartz reefs and mylonite zones in parts of Bundelkhand Granitoid Complex, southern U.P. Final Report (FSP 1995-1997), Geological Survey of India (NR), 77 p. (Unpublished).

Pati, J.K., 1999, Stage Review Report on specialized thematic study of older enclaves (migmatites, gneisses and supracrustals) within the Bundelkhand Granitoid Complex in southern U.P. Geological Survey of India (NR), 7 p. (Unpublished).

Pati, J.K., 2000, Specialized thematic study of older enclaves (migmatites, gneisses and supracrustals) within the parts of Bundelkhand Granitoid Complex (BUGC). Geological Survey of India Records, v. 132, pp. 95-96.

Pati, J.K., 2005, The Dhala Structure, Bundelkhand craton, Central India-A new large Paleoproterozoic impact structure. Meteoritics \& Planetary Science 40, abstract \#A121.

Pati, J.K. and Panigrahi, M. K., 2005, Molybdenite-bearing granitoids from Bundelkhand craton and the nature of mineralising fluid. National Seminar on Proterozoic Systems of India: Evolution and Economic Potential, Indian School of Mines, Dhanbad, 30 pp.

Pati, J.K., Augé, T., Raju, S. and Prakash, K., 2005, First report of PGE mineralization in metamorphosed mafic-ultramafic rocks of Madaura area, Bundelkhand craton, Central India. 10th Platinum International Symposium, Geological Survey of Finland, 
Finland, pp. 524-526.

Pati, J.K., Malviya, V.P., and Arima, M., 2006, Bundelkhand Tectonic Zone- A crustal-scale deformed corridor in the Central Indian Shield. National Seminar on Active and Fossil Suture Zones and AGM, Geological Society of India, 2006, Dehradun, 137 pp.

Pati, J.K., Prakash, K., Raju, S. and Bhusan, R., 2006, Metamorphosed mafic-ultramafic rocks of Madaura area, Bundelkhand craton, Central India and their PGE mineralization potential. National Seminar on "Evolution of Mineral Resources of India”, $8^{\text {th }}$ National Convention of South Asian Association of Economic Geologists (India Chapter), Andhra University, Visakhapatnam, pp.20-21.

Pati, J.K., 2007, Cu-Pb-Zn Mineralization along the Bundelkhand Tectonic Zone (BTZ) - a case study from Kabrai area, Archean Bundelkhand Craton (ABC), Central India. Magmatism, Tectonism and Mineralization (MTM-2007)" and X Convention of South Asian Association of Economic Geologist (SAAEG India Chapter), Department of Geology, Kumaun University, Nainital, pp. 122-124.

Pati, J.K., Patel, S.C., Pruseth, K.L., Malviya, V.P., Arima, M., Raju, S., Pati, P., Prakash, K., 2007, Geology and geochemistry of giant quartz veins from the Bundelkhand Craton, central India and their implications. Journal of Earth System Sciences, v. 116, pp. 497510.

Pati, J.K. and Reimold, W.U., 2007, Impact cratering - fundamental process in geoscience and planetary science. Journal of Earth System Science,v. 116, pp. 81-98.

Pati, J.K., Reimold, W.U., Koeberl, C., and Pati, P., 2008a, The Dhala structure, Bundelkhand Craton, Central India-eroded remanant of a large Paleoproterozoic impact structure. Meteoritics \& Planetary Science, v. 43, pp. 1383-1398.

Pati, J.K., Raju, S., Malviya, V.P., Bhusan, R., Prakash, K. and Patel, S.C., 2008b, Mafic Dykes of Bundelkhand Craton, Central India: Field, Petrological and Geochemical Charcteristics. In: Srivastava, R.K., Sivaji, Ch. and Rao, N.V.C. (Eds.), Indian Dykes: Geochemistry, Geophysics and Geochronology, Narosa Publishing House, New Delhi, India., pp. 547-569.

Pati, J.K., Jourdan, F., Armstrong, R.A., Reimold, W.U., and Prakash, K., 2010, First SHRIMP U-Pb and ${ }^{40} \mathrm{Ar} /{ }^{39} \mathrm{Ar}$ chronological results from impact melt breccia from the Paleoproterozoic Dhala impact structure, India. In: Reimold, W.U., and Gibson, R.L., (Eds.), Large Meteorite Impacts and Planetary Evolution IV, Geological Society of America, Special Paper, v. 465, pp. 571-591.

Pati, J.K., 2010, Organo-sedimentary structures of Archean age in a pre-impact high-grade rock within the Dhala impact structure, central India. SEPM Field Conference on Microbial Mats in Siliciclastic Deposits (Archean to Today), Denver, Colorado, USA (Abstract).

Pati, J.K. and Saha, L., 2011, Mesoarchaean tectono-metamorphic event from Bundelkhand craton, central India. Goldschmidt Conference, Prague, Abstract, p. 23.

Pati, J.K., Panigrahi, M.K. and Chakarvorty, M., 2014, Granite-hosted molybdenite mineralization from Archean Bundelkhand cratonmolybdenite characterization, host rock mineralogy, petrology, and fluid inclusion characteristics of Mo-bearing quartz. Journal of Earth System Science, v. 123, pp. 943-958.

Pati, J.K., Reimold, W.U., Greshake, A., Schmitt, R.T., Koeberl, C., Pati, P. and Prakash, K., 2015, Pseudotachylitic breccia from the Dhala impact structure, north-central India: texture, mineralogy and geochemical characterization. Tectonophysics, v. 649, pp. 18-32.

Pati, J.K., Qu, W.J., Koeberl, K., Reimold, W.U., Chakarvorty, M., and Schmitt, R.T., 2017, Geochemical evidence of an extraterrestrial component in impact melt breccias from the
Paleoproterozoic Dhala impact structure, India. Meteoritics \& Planetary Science, v. 52, pp. 722-736.

Pati, J.K., Poelchau, M.H., Reimold, W.U., Nakamura, N., Kuriyama, Y., and Singh, A.K., 2019, Documentation of shock features in impactites from the Dhala impact structure, India. Meteoritics \& Planetary Science, v. 54, pp. 2312-2333

Peucat, J.-J., Mahabaleshwar, B. and Jayananda, M., 1993, Age of younger tonalitic magmatism and granulite metamorphism in the south Indian transition zone (Krishnagiri area): comparison with older peninsular gneisses from Hassan-Gorur area. Journal of Metamorphic Geology, v. 11, pp. 879-888.

Peucat, J.-J., Bouhallier, H., Fanning, C.M. and Jayananda, M., 1995, Age of Holenarsipur greenstone belt, relationships with the surrounding gneisses (Karnataka, south India). Journal of Geology, v. 103, pp. 701-710.

Pradhan, V.R., Meert, J.G., Pandit, M.K., Kamenov, G., Gregory, L.C. and Malone, S., 2010, India's changing place in global Proterozoic reconstructions: new geochronologic constraints on key paleomagnetic poles from the Dharwar and Aravalli/Bundelkhand Cratons. Journal of Geodynamics, v. 50, pp. 224-242.

Pradhan, V.R., Meert, J.G., Pandit, M.K., Kamenov, G. and Mondal, M.E.A., 2012, Paleomagnetic and geochronological studies of the mafic dyke swarms of Bundelkhand craton, central India: implications for the tectonic evolution and paleogeographic reconstructions. Precambrian Research, v. 198-199, pp. 51-76.

Prakash, R., Swarup, P. and Srivastava, R.N., 1975, Geology and mineralization in the southern parts of Bundelkhand in Lalitpur district, Uttar Pradesh. Journal of the Geological Society of India, v. 16, pp. 143-156.

Prasad, M.H., Hakim, A., Krishna Rao, B., 1999, Metavolcanic and metasedimentary inclusions in the Bundelkhand Granitic Complex in Tikamgarh district, MP. Journal of the Geological Society of India, v. 54, pp. 359-368.

Radhakrishna, T., Chandra, R., Shrivastava, A.K., and Balasubramonian, G., 2013, Central/Eastern Indian Bundelkhand and Bastar cratons in the Palaeoproterozoic supercontinental reconstructions: A palaeomagnetic perspective. Precambrian Research, v. 226, pp. 91-104.

Rajesh, H.M., Mukhopadhyay, J., Beukes, N.J.,Gutzmer, J., Belyanin, G.A. and Armstrong, R. A., 2009, Evidence of an early Archaean granite from Bastar Craton, India. Journal of the Geological Society, London, v. 166, pp. 193-196.

Ramakrishnan, M., Venkatadasu, S.P. and Kröner, A., 1994, Middle Archaean age of Sargur Group by single grain zircon dating and geochemical evidence for the clastic origin of metaquartzite from J.C. Pura Greenstone belt, Karnataka. Journal of the Geological Society of India, v. 44, pp. 605-616.

Ram Mohan, M., Singh, S.P., Santosh, M., Siddiqui, M.A. and Balaram, V., 2012, TTG suite from the Bundelkhand Craton, Central India: Geochemistry, petrogenesis and implications for Archean crustal evolution. Journal of Asian Earth Sciences, v. 58, pp. 38-50.

Ramiz, M.M. and Mondal, M.E.A., 2017, Petrogenesis of mafic magmatic enclaves of the Bundelkhand granitoids near Orchha, Central Indian shield: evidence or rapid crystallization. In: Halla, J., Whitehouse, M.J., Ahmad, T., Bagai, Z. (Eds.), Crust-Mantle Interactions and Granitoid Diversification: Insights from Archaean Cratons. Geological Society of London, Special Publications, v. 449, pp. 123-157.

Ramiz, M.M., Mondal, M.E.A. and Farooq, S.H., 2018, Geochemistry of ultramafic-mafic rocks of the Madawara Ultramafic Complex in the southern part of the Bundelkhand Craton, Central Indian Shield: Implications for mantle sources and geodynamic setting. Geological Journal, pp. 1-23. 
Ray, L., Nagaraju, P., Singh, S.P., Ravi, G. and Roy, S., 2015, Radioelemental, petrological and geochemical characterization of the Bundelkhand craton, central India: implication in the Archaean geodynamic evolution. International Journal of Earth Sciences, v. 105, pp. 1087-1107.

Rao, J.M., Rao, P., Widdowson, M. and Kelley, S.P., 2005, Evolution of Proterozoic mafic dyke swarms of the Bundelkhand Granite Massif, Central India. Current Science, v. 88, pp. 502-506.

Roday, P.P., Diwan, P. and Singh, S., 1995, A kinematic model of emplacement of quartz reef and subsequent deformation pattern in the Central Indian Bundelkhand batholith.Proceedings of the Indian Academy of Science V, v. 104, pp. 465-488.

Ross, M., 1981, The geological occurrences and health hazards of amphibole and serpentine asbestos. In: Veblen, D.R. (Ed.), Amphiboles and other hydrous Pyriboles-Mineralogy. Reviews in Mineralogy, Mineralogical Society of America, v. 9A, pp. 279323.

Rout, D., Panigrahi, M.K. and Pati, J.K., 2017, Fluid Characteristics in the Giant Quartz Reef System of the Bundelkhand Craton, India: Constraints from Fluid Inclusion Study. American Geophysical Union Fall Meeting, New Orleans, Louisiana, USA (December, 2017), Abstract No. V43B-0540.

Roy, A.B., Kröner, A., Rathore, S., Laul, V. and Purohit, R., 2012, Tectono-metamorphic and geochronologic studies from Sandmata Complex, north west Indian shield: implications on exhumation of Late-Palaeoproterozoic granulites in an Archaean-early Palaeoproterozoicgranite-gneiss terrane. Journal of the Geological Society of India,v. 79, pp. 323-334.

Roy, M., Pandey, P., Kumar, S. and Singh, R.P., 2018, A petrological and geochemical account of subsurface noritic intrusion in the western part of Bundelkhand massif, Shivpuri district, M.P. Journal of the Geological Society of India, v. 91, pp. 147-157.

Saha, A.K., Bose, R., Ghosh, S.N. and Roy, A., 1977. Petrology and emplacement of Mayurbhanj Granite batholith, eastern India. Evolution of orogenic belts of India (Part 2). Bulletin of the Geological Mineralogical Meteorological Society of India, v. 49, pp. 1-34.

Saha, L., Pant, N.C., Pati, J.K., Upadhyay, D., Berndt, J., Bhattacharya, A., Satyanarayanan, M., 2011, Neoarchean high-pressure margarite-phengitic muscovite-chlorite corona mantled corundum in quartz-free high-Mg, $\mathrm{Al}$ phlogopite-chlorite schists from the Bundelkhand Craton, north central India. Contributions to Mineralogy and Petrology, v. 161, pp. 511-530.

Saha, L., Frei, D., Gerdes, A., Pati, J.K., Sarkar, S., Patole, V., Bhandari A., and Nasipuri, P., 2016, Crustal geodynamics from the Archaean Bundelkhand Craton, India: constraints from zircon U-Pb-Hf isotope studies. Geological Magazine, v. 153, pp. 79-192.

Sarangi, S., Gopalan, K., and Kumar, S., 2004, Pb-Pb age of earliest megascopic eukaryotic alga bearing Rohtas Formation, Vindhyan Supergroup, India: Implications for Precambrian atmospheric oxygen evolution. Precambrian Research, v. 132, pp. 107-121.

Sarkar, A., Trivedi, J.R., Gopalan, K., Singh, P.N., Das, A.K. and Paul, D.K., 1984, Rb-Sr geochronology of Bundelkhand granitic complex in the Jhansi-Babina-Talbehat sector,UP, India. Indian Journal of Earth Science, CEISM Seminar Volume, 64-72.

Sarkar, A., Paul, D.K. and Potts, P.J., 1996, Geochronology and geochemistry of Mid-Archean trondhjemitic gneisses from the Bundelkhand craton, central India. Recent Researches in Geology, v. 16 , pp. 76-92.

Sarkar, A., Ghosh, S., Singhai, R.K., Gupta, S.N., 1997, Rb-Sr geochronology of the Dargawan sill: constraint on the age of the type Bijawar sequence of Central India. In: International Conference on isotopes in Solar System, (November 1997), v. 5, pp. 100-101.
Satyanarayanan, M., Balaram, V., Roy, P., Anjaiah, K.V. and Singh, S.P., 2010, Trace, rare earth element (REE) and platinum group element (PGE) geochemistry of the mafic and ultramafic rocks from Bundelkhand craton, Central India. In: Satake, K. (Ed.), Advances in geosciences, World Scientific Publishing Company, v. 20, pp. 57-79.

Satyanarayanan, M., Singh, S.P., Balaram, V., and Niranjan, M., 2015, Geochemistry of the Madawara Igneous Complex, Bundelkhand Craton, Central India: Implications for PGE Metallogeny. Open Geosciences, v. 7, pp. 836-853.

Seifert, W., Rhede, D., Thomas, R., Forster, H.-J., Lucassen, F., Dulski, P. and Wirth, R., 2011, Distinctive properties of rock-forming blue quartz: inferences from a multi-analytical study of submicron mineral inclusions. Mineralogical Magazine, v. 75, pp. 2519-2534.

Senthiappan, M., 1976, Geology of the area along the Raksa Shear zone, Jhansi district, Uttar Pradesh. Symposium on the Archaean of central India, GSI, Nagpur, Abstract, p. 22.

Senthiappan, M., 1981, Geology of the area along the Raksa Shear zone, Jhansi district, Uttar Pradesh. Special Publication, Geological Survey of India, v. 3, pp. 73-76.

Sharma, K.K. and Rahman, A., 2000, The Early ArchaeanPaleoproterozoic crustal growth of the Bundelkhand craton, northern Indian shield. In: Deb, M. (ed.), Crustal Evolution and Metallogeny in the Northwestern Indian Shield, Narosa publication, New Delhi, pp. 51-72.

Sharma, R.P., 1979, Origin of the pyrophyllite-diaspore deposits of the Bundelkhand Complex, Central India. Mineralium Deposita, v. 14, pp. 343-352.

Sharma, R.P., 1982, Lithostratigraphy, structure and petrology of the Bundelkhand group. In: Valdia, K.S., Bhatia, S.B. and Gaur, V.K. (Eds.), Geology of Vindhyanchal, pp. 30-46.

Shukla, R. and Singh, D.P., 1997, Specialized thematic studies of Bundelkhand Granitoids for appraisal of the mode of occurrence of molybdenum and associated mineralization, Rauli Kalyanpur area, Banda districts, U.P. Geological Survey of India Records, v. 129, pp. 141-142.

Singh, A., Singh, C. and Kennett, B., 2015, A review of crust and upper mantle structure beneath the Indian subcontinent. Tectonophysics, v. 644-645, pp. 1-21.

Singh, A., Ravi Kumar, M., Mohanty, D. D., Singh, C., Biswas, R., and Srinagesh, D., 2017, Crustal Structure Beneath India and Tibet: New Constraints From Inversion of Receiver Functions. Journal of Geophysical Research: Solid Earth, v. 122, pp. 78397859.

Singh, P. K., Verma, S. K., Singh, V. K., Moreno, J. A., Oliveira, E. P., and Mehta, P., 2019, Geochemistry and petrogenesis of sanukitoids and high-K anatectic granites from the Bundelkhand Craton, India: Implications for late-Archean crustal evolution. Journal of Asian Earth Sciences, v. 174, pp. 263-282.

Singh, P. K., Verma, S. K., Moreno, J. A., Singh, V. K., Malviya, V. P., Oliveira, E. P., Mishra, S., Arima, M., 2019, Geochemistry and Sm-Nd isotope systematics of mafic-ultramafic rocks from the Babina and Mauranipur greenstone belts, Bundelkhand Craton, India: Implications for tectonic setting and Paleoarchean mantle evolution. Lithos, v. 330-331, pp. 90-107.

Singh, S.P., Balaram, V., Satyanarayanan, M., Anjaiah K.V., Kharya, A., 2010, Madawara ultramafic omplex in Bundelkhand Craton: A new PGE repository for exploration in Central India. Journal of Economic Geology and Georesource Management, v. 7, pp. 54-71.

Singh, S.P., Singh, M.M., Srivastava, G.S. and Basu, A.K., 2007, Crustal evolution in Bundelkhand area, Central India. Journal of Himalayan Geology, v. 28, pp. 79-101.

Singh, S.P., Dwivedi, S.B., 2009, Garnet sillimanite-cordierite-quartz 
bearing assemblages from the early Archean supracrustal rocks of Bundelkhand Massif Central India. Current Science, v. 97, pp. 103-107.

Singh, S.P., Balaram, V., Satyanarayanan, M., Anjaiah, K.V. and Kharia, A., 2010, Platinum group elements in basic and ultrabasic rocks around Madawara, Bundelkhand Massif, Central India. Current Science, v. 99, pp. 375-383.

Singh, S.P., Balaram, V., Satyanarayanan, M., Sarma, D.S., Subramanyam, K.S.V., Anjaiah, K.V. and Kharia, A., 2011, Platinum group minerals from the Madawara Ultramafic mafic Complex, Bundelkhand Massif, Central India: A preliminary note. Journal of Geological Society of India, v. 78, pp. 281-283.

Singh, S.P., Dwivedi, S.B., 2015, High grade metamorphism in the Bundelkhand Massif and its implications on Mesoarchean crustal evolution in Central India. Journal of Earth System Science, v. 124, pp. 197-211.

Singh, S.P., Singh, M.M., Srivastava, G.S. and Basu, A.K., 2007, Crustal evolution in Bundelkhand area, Central India. Journal of Himalayan Geology, v. 28, pp. 79-101.

Singh, S.P., Subramanyam, K.S.V., Manikyamba C., Santosh, Singh, M.R., and Kumar, B.C., 2018, Geochemical systematic of the Mauranipur-Babina greenstone belt, Bundelkhand Craton, Central India: Insights on Neoarchean mantle plume-arc accretion and crustal evolution. Geoscience Frontiers, v. 9, pp. 769-788.

Singh, V.K., Slabunov, A., 2015, Geochemical characteristics of Banded Iron Formation and Metavolcanics from Babina greenstone belt of the Bundelkhand Craton, Central India. Journal of Economic Geology and Georesource Management, v. 10, pp. 63-74.
Singh, V.K. and Slabunov, A., 2015, The Central Bundelkhand Archaean greenstone complex, Bundelkhand craton, Central India: Geology, composition, and geochronology of supracrustal rocks. International Geology Review, v. 57, pp. 1349-1364.

Singh, V.K., Slabunov, A., 2016, Two types of Archaean supracrustal belts in the Bundelkhand craton, India: Geology, geochemistry, age and implication for craton crustal evolution. Jounral of the Geological Society of India, v. 88, pp. 539-548.

Slabunov, A., Singh, V.K., Joshi, K.B., and Li, X., 2017, Paleoarchean zircons from quartzite of South Bundelkhand Supracrustal Complex: The origin and Implications for Crustal evolution in Bundelkhand Craton, Central India. Current Science, v. 112, pp. 794-801.

Slabunov, A. and Singh, V.K., 2018, Meso-Neoarchaean crustal evolution of the Bundelkhand Craton, Indian Shield: new data from greenstone belts. International Geology Review, pp. 1-20.

Van Hunen, J. and Moyen, J.-F., 2012, Archean subduction: fact or fiction? Annual Review of Earth and Planetary Sciences, v. 40, pp. 195-219.

Verma, S.K., Verma, S.P., Oliveira, E.P., Singh, V.K., Moreno, J.A., 2016, LA-SF-ICP-MS zircon U-Pb geochronology of granitic rocks from the central Bundelkhand greenstone complex, Bundelkhand craton, India. Journal of Asian Earth Sciences, v.118, pp.125-137.

Wiedenbeck, M. and Goswami, J.N., 1994, An ion-probe single zircon ${ }^{207} \mathrm{~Pb} /{ }^{206} \mathrm{~Pb}$ age from the Mewar Gneiss at Jhamarkotra, Rajasthan. Geochimica et Cosmochimica Acta, v. 58, pp. 2135-2141.

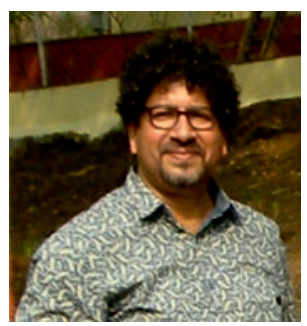

Professor Jayanta Kumar Pati, Department of Earth and Planetary Sciences, University of Allahabad is a trained experimental petrologist and has contributed significantly to the geology of Bundelkhand Craton, India. He is also involved in terrestrial impact cratering research and the study of planetary analogues. He confirmed the impact origin of Dhala structure, India. He has published more than 80 research papers in national and international journals. Professor Pati is the Director of National Centre of Experimental Mineralogy and Petrology, AU. 